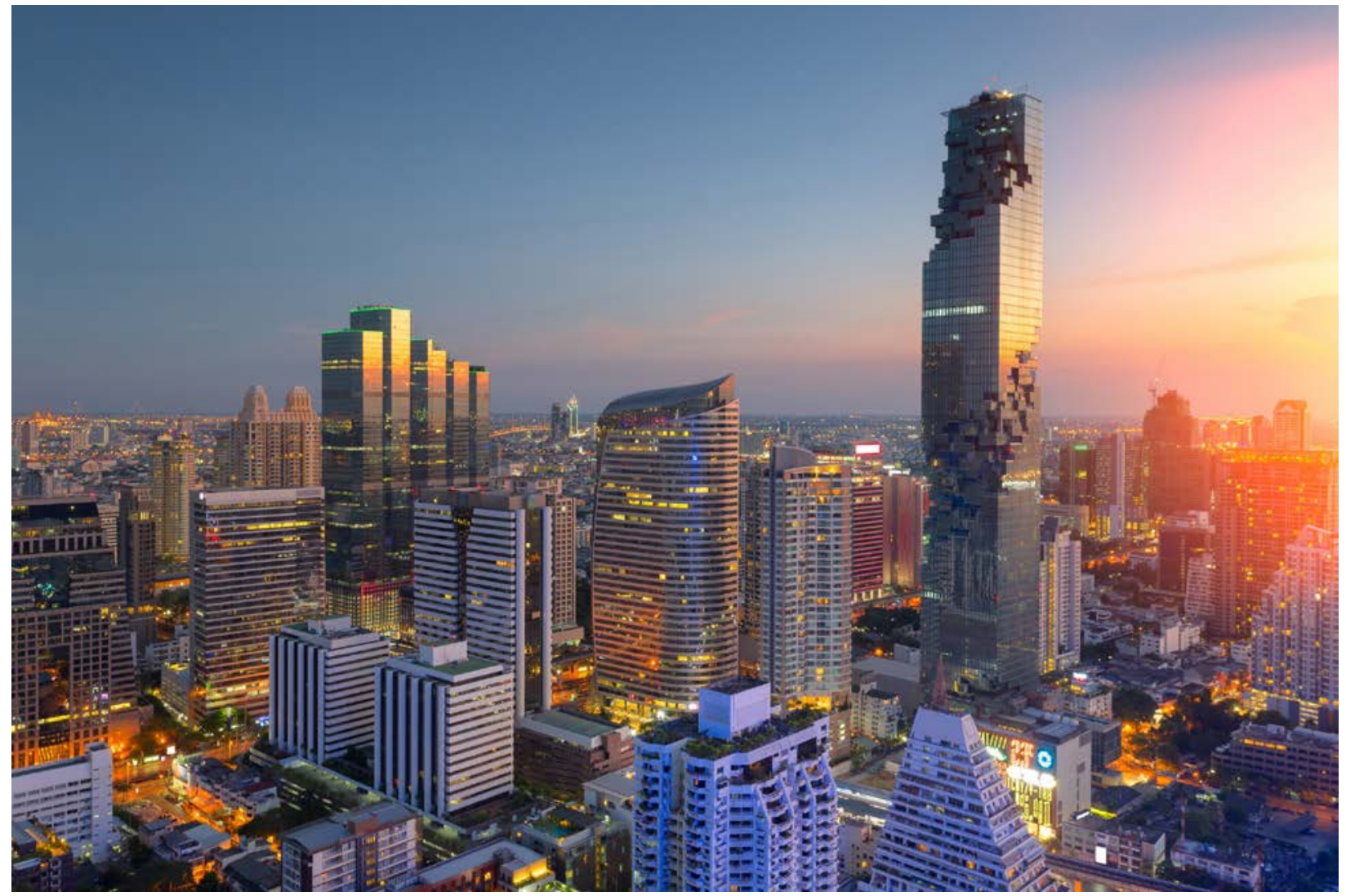

\title{
COVID-19 AND THE POWER SECTOR IN SOUTHEAST ASIA: IMPACTS AND OPPORTUNITIES
}

Travis Lowder, and Nathan Lee, Ph.D. National Renewable Energy Laboratory

Jennifer E. Leisch, Ph.D. Two Degrees Group

June 2020

A product of the USAID-NREL Partnership Contract No. IAG-19-2115 


\section{NOTICE}

This work was authored, in part, by the National Renewable Energy Laboratory (NREL), operated by Alliance for Sustainable Energy, LLC, for the U.S. Department of Energy (DOE) under Contract No. DEAC36-08GO28308. Funding provided by the United States Agency for International Development (USAID) under Contract No. IAG-19-2115. The views expressed in this report do not necessarily represent the views of the DOE or the U.S. Government, or any agency thereof, including USAID.

This report is available at no cost from the National Renewable Energy Laboratory (NREL) at www.nrel.gov/publications.

U.S. Department of Energy (DOE) reports produced after 1991 and a growing number of pre-1991 documents are available free via www.OSTI.gov.

Cover photo from iStock 58861883.

NREL prints on paper that contains recycled content. 


\section{Acknowledgments}

The authors wish to thank Scott Bartos of the U.S. Agency for International Development (USAID) Regional Development Mission for Asia for conceiving of and funding this work, and for his guidance during its development. We also express our deep gratitude for all the peer reviewers on this report, including Ananth Chikkatur and Ha Dong Son of the Vietnam Low Emission Energy Program, Leonila Gutierrez of USAID Philippines, Peerapat Vithayasrichareon of the International Energy Agency, Dana Kenny, Winston Chow, Thanawat ("Yok") Keereepart, Pitoon ("PJ") Junthip, Maythiwan ("May") Kiatgrajai, and Joost Siteur of USAID Clean Power Asia, Sherry Stout and Andrea Watson of the National Renewable Energy Laboratory (NREL), and Thomas Haslett of USAID E3. We also appreciate the graphics support from Billy Roberts of NREL. Last, we would like to thank Isabel McCan, Liz Breazeale, and the NREL Communications team for their efforts in refining this report and bringing it to publication. 
Advanced Energy Partnership for Asia

\section{List of Acronyms}

ASEAN
CDC
COVID-19
GDP
IEA
IPP
NGCP
NREL
PLN
PPA
SE
USAID
WHO

Association of Southeast Asian Nations

Centers for Disease Control and Infection

coronavirus disease

gross domestic product

International Energy Agency

independent power producer

National Grid Corporation of the Philippines

National Renewable Energy Laboratory

Perusahaan Listrik Negara

power purchase agreement

southeast

U.S. Agency for International Development

World Health Organization 


\section{Table of Contents}

1 COVID-19 and the Power Sector in Southeast Asia .................................................................... 1

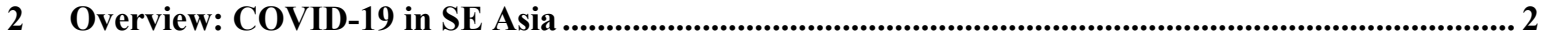

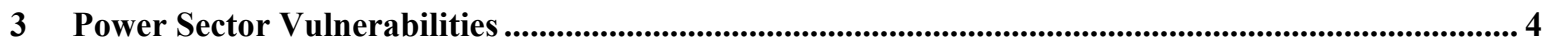

3.1 Increasing Severity and Frequency of Natural Threats.................................................4

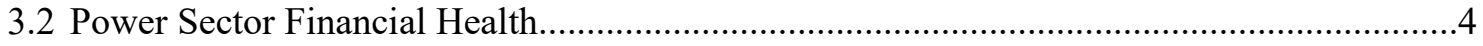

3.3 Fuel Mix and Fossil Fuel Reliance ........................................................................5

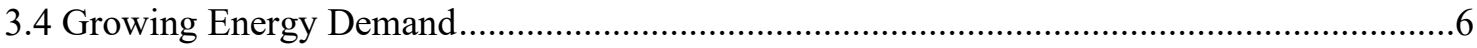

3.5 Air Quality and Pollution ..............................................................................

4 COVID-19 Impacts on the Power Sector............................................................................................8 8

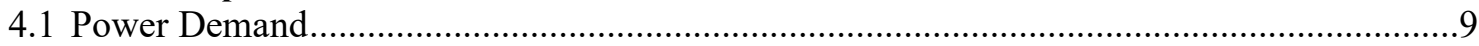

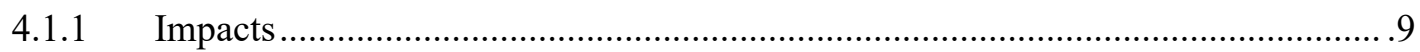

4.1.2 Opportunities and Recovery Responses.............................................. 12

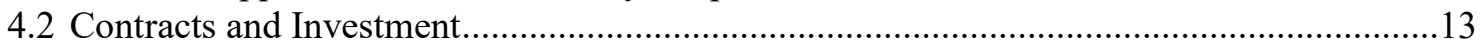

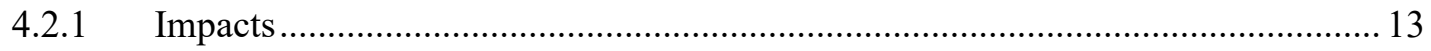

4.2.2 Opportunities and Recovery Responses..................................................... 14

4.3 Air Quality and Emissions ............................................................................ 14

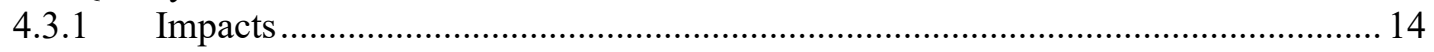

4.3.2 Opportunities and Recovery Responses.................................................... 14

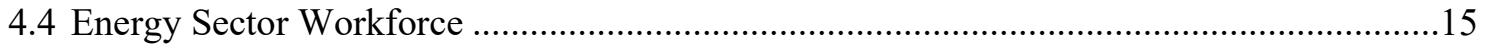

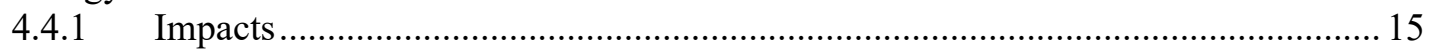

4.4.2 Opportunities and Recovery Responses..................................................... 15

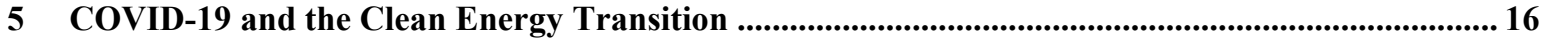

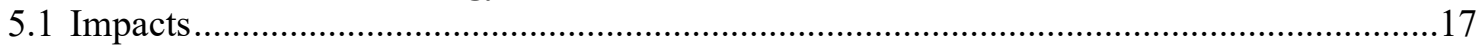

5.2 Clean Energy Opportunities and Recovery Responses.............................................. 17

6 Building Long-Term Energy Sector Resilience.................................................................................... 19

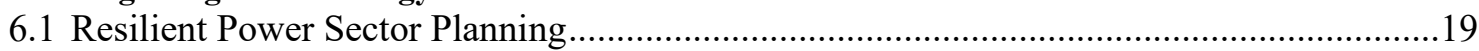

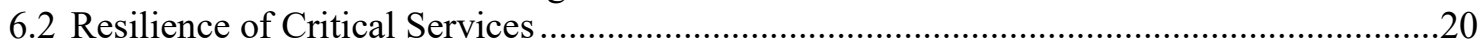

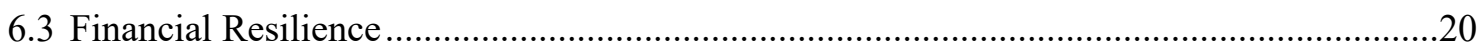

6.4 Clean Energy and Power System Resilience ............................................................20

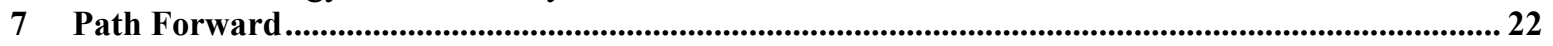




\section{List of Figures}

Figure 1. Total disasters reported in SE Asia from July 2012 to June 2018 ......................................... 4

Figure 2. Financial conditions of select SE Asian power sectors ........................................................ 5

Figure 3. Power sector generation mix (installed capacity) in SE Asia 2000-2018 ............................... 6

Figure 4. Singapore systemwide electricity demand during the second week of April in 2019 and 2020 . 10

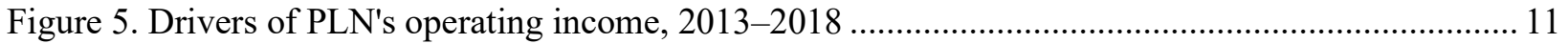

Figure 6. Share of global economic and energy indicators in SE Asia ............................................... 16

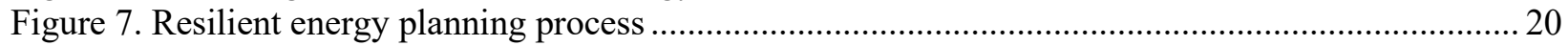

\section{List of Tables}

Table 1. SE Asia Pandemic Response in 2020 .................................................................................. 2

Table 2. GDP Growth and Projected Growth Rates for SE Asia with COVID-19 Impacts (\% per year) .... 3

Table 3. Impacts of COVID-19 to SE Asia Power Sector and Recovery Responses/Opportunities ............ 8

Table 4. Power Sector Entities Along the Electricity Value Chain ........................................................ 9 


\section{COVID-19 and the Power Sector in Southeast Asia}

In just a few months, the coronavirus disease (COVID-19) pandemic has taken a significant toll on populations and economies across the globe. The International Monetary Fund projected that global gross domestic product (GDP) could contract by up to $3 \%$ in 2020 as a result of the "Great Lockdown," or government-mandated closure of businesses, border closures, and stay-at-home orders across the world aimed at preventing greater infection and deaths from COVID-19 (IMF 2020). The World Bank estimate is even higher, at 5.2\%. (World Bank 2020a). These lockdowns have helped to reduce the spread of disease; however, the protracted economic inactivity has also resulted in a number of supply and demand shocks across the world (World Bank 2020b).

In the power sector, these lockdown measures depressed commercial and industrial sector electricity consumption and increased electricity demand in the residential sector, effectively mimicking a Sunday load curve through every day of the week. Overall electricity demand has decreased, with some countries reporting up to a $20 \%$ drop in consumption during periods of full lockdown. This is demand destruction on a scale not seen over the last 70 years, and it has come with a corresponding dive in electricity commodity prices (IEA 2020a). Reliable, low-cost energy is essential to the pandemic response and economic recovery.

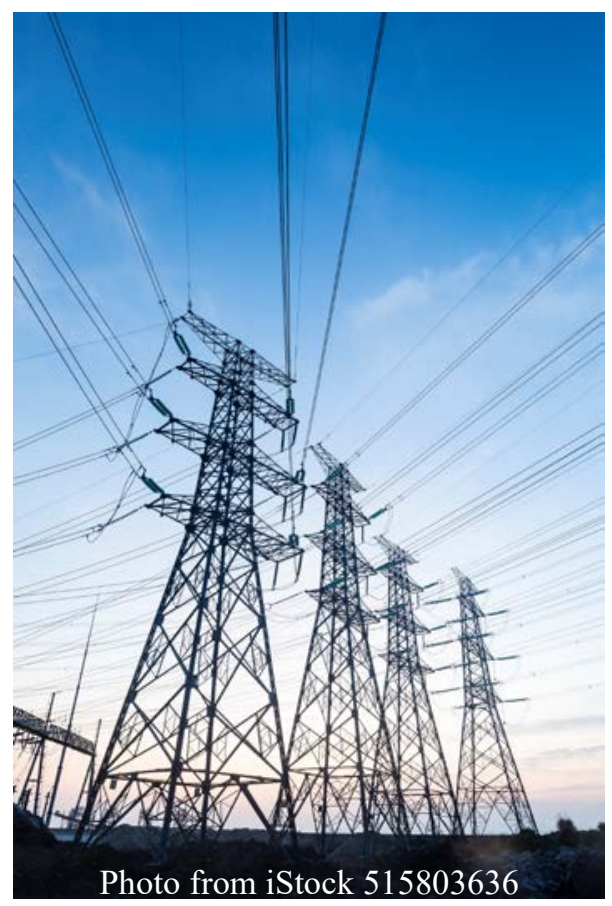

Power sectors across the globe are now experiencing ripple effects. System operators face workforce and supply chain disruptions, modified control center protocols, and the challenge of forecasting demand in a time of heightened uncertainty (Walton 2020). Energy utilities, experiencing reduced electricity sales, are receiving less revenue relative to their projections, straining their cost recovery on rate-based infrastructure, which may lead to higher retail prices in the future (Kaushik, Kimbrough, and McKaughan 2020). Independent power producers (IPPs) are also receiving less operational revenue (resulting from lower overall demand and lower wholesale electricity prices), which could force project loan defaults (Rios 2020). New renewable energy generation is challenged by the invocation of force majeure clauses, low wholesale energy prices, supply chain issues, and other factors (Stebbing, Down, and Emmet 2020). Nevertheless, renewables are currently the only generation type showing resilience to pandemic lockdown measures. Renewable generation has increased by nearly $3 \%$ worldwide, largely due to a wave of projects that came online before the pandemic, and their primary placement in the merit order of dispatch (such as "must run" generation). In the longer term, reduced demand and supply chain disruptions could delay the construction of new renewable energy projects (IEA 2020a).

While these are global trends, each country or region is experiencing unique impacts. Southeast (SE) Asia, a region of rapid economic growth and increasing energy demand, faced unique power sector vulnerabilities (such as exposure to natural threats, strained finances, and reliance on fossil fuels, among others) prior to this pandemic that may pose even greater risks in today's volatile market conditions. COVID-19 is exposing some of these vulnerabilities in the region; however, it also presents an opportunity to safeguard the reliable, sustainable, and low-cost provision of power. As governments in SE Asia deliberate over the most effective means of combatting the economic damage from the COVID-19 pandemic, the region has an opportunity to couple economic recovery with a roadmap to achieve broader power sector resilience, human health, and climate objectives.

The purpose of this report is twofold:

1. Present an early assessment of COVID-19 impacts on the power sectors of countries in SE Asia.

2. Identify opportunities to build power sector resilience as SE Asian countries respond to and recover from these impacts.

The impacts of the COVID-19 pandemic are rapidly evolving across the globe, and a more comprehensive assessment of the consequences will become easier with hindsight. Instead, this work intends to provide early insights and potential actions countries may take during the course of recovery. 


\section{Overview: COVID-19 in SE Asia}

The World Health Organization (WHO) reported over 7.27 million confirmed cases of COVID-19 worldwide as of June $11^{\text {th }}, 2020$, with over 400,000 attributed deaths (WHO 2020b). Across SE Asia, the confirmed case count has been growing, though some countries have enacted early and aggressive measures which have successfully slowed transmission within their borders. In some cases, such as Vietnam and Singapore, actions to stem pandemic impacts were heavily informed by experience with the $2003-2004$ SARS epidemic. The range of SE Asian country-level pandemic control and economic stimulus responses is compiled in Table 1.

\section{Table 1. SE Asia Pandemic Response in 2020}

\section{Country Pandemic Control Response}

On March 16, Brunei enacted travel restrictions for citizens and foreigners and prohibited mass gatherings, weddings,

Brunei and sporting events. This was expanded to ban foreign visitors on March 24.

On March 18, Cambodia closed locations and canceled events to prevent large public gatherings. Travel restrictions were also put in place, previously on March 14. The country

Cambodia also placed foreign visitors under 14-day quarantine upon entry.

On March 31, Indonesia temporarily banned foreign visitors to the country and declared a health emergency allowing for regional social restrictions to be put in place for public

Indonesia gatherings. On April 10, the country enacted social restriction measures for the city of Jakarta, which closed public gathering spaces. Other lockdown measures were applied separately in regions of the country.

On March 30, the Lao PDR closed all international borders until May 3. This was extended with a process to allow entry for certain foreigners. On the same date the government

Lao PDR issued a national stay-at-home order and international border closures. Government employees have returned to work on a staggered basis.

\section{Economic Stimulus Response}

After announcing temporary economic measures on March 19, Brunei Darussalam announced additional financial support (\$317 million) on March 30, 2020. The Economic Relief Package includes deferred payments on loans and waivers on bank fees/changes.

On March 9, Cambodia allocated between \$800 million and \$2 billion for small and medium enterprises. On April 3, the Ministry of Economy and Finance established a working group to plan monetary and banking measures, a task force to control supply and prices of strategic goods and a task force to plan for budget policy on financing and social assistance.

In February, the government announced a stimulus package of $\$ 725$ million to support key industries and $\$ 325$ million for lowincome families. On March 18, Indonesia announced an \$8.1 billion package for private and corporate tax breaks. On March 31 , a third stimulus package of $\$ 24.5$ billion was introduced for health, social protection and tax incentives. Another package was announced on May 18 to proactively prevent economic impact for large enterprises and social programs.

On March 20, the Lao cabinet approved a stimulus package and tax relief measures for small businesses. On April 7, the World Bank's Regional Vice-Presidency of the East Asia and Pacific Region approved the Lao PDR COVID-19 Response Project of $\$ 18$ million. On April 10, Lao PDR implemented tax breaks and exemptions.

From February 27 to April 6, three stimulus packages were announced totaling $\$ 9.1$ billion to support key industries (such as tourism) and employees, low-income households, small and medium enterprises, and tax deductions.

On March 18, the government enabled certain companies to apply for low-interest rate loans from a relief fund of $\$ 71$ million. On April 27, the government released an economic relief plan to encourage business and trade and provide social support. This may be followed by a $\$ 2-3$ billion stimulus package.

On March 30, a $\$ 3.9$ billion package for social protections was announced. On April 7, the government released $\$ 610$ million in support to local governments. On April 13, a \$1 billon wage subsidy package was announced. On May 12, the government approved a stimulus act to create jobs in rural areas with projects valued at $\$ 29$ billion.

Singapore has announced three COVID response budgets ("Unity," "Resilience," and "Fortitude") totaling $\$ 97$ billion since February. These budgets include individual and commercial support measures, including cash payments, subsidies, and

worker support.
Singapore visitors. On April 7, Singapore adopted a "Circuit Breaker", a set of elevated safe distancing measures that closed public gathering spaces and limited movement in the country. 
On March 22, Thailand closed all borders and banned foreign visitors from certain countries. On April 3, Thailand enacted a nightly curfew and banned inbound commercial

Thailand flights through June 30 . This was extended to include closing non-essential businesses, and spaces with large public gatherings on March 26, though some service businesses following required procedures opened in May.

\section{On February 1, Vietnam temporarily banned flights to and}

from China. On February 13, Vietnam enacted a large scale

Vietnam
On March 10, Thailand unveiled a $\$ 12.7$ billon government stimulus package to support the economy. On March 22, the government announced a plan for commercial banks to borrow from a central bank lending facility using investment grade bonds as collateral. On April 7, the government announced a stimulus package worth $\$ 58$ billion to aid workers, infrastructure, and small and medium enterprises.

\section{On March 3, the government announced a \$1.16 billion}

stimulus package with tax breaks and earmarks for government infrastructure spending. In April, Vietnam also released a \$2.6 billion stimulus package to support workers and tax collection essential services, schools, and social distancing. On April 1, billion stir
the country started a national lockdown and social isolation delays. measures.

Sources: (Singapore Ministry of Health 2020; U.S. News \& World Report 2020; U.S. Embassy in Cambodia 2020; Center for Strategic \& International Studies 2020; KPMG 2020)

SE Asia, like the rest of the world, is experiencing an economic downturn from the pandemic; however, growth forecasts project that several countries in the region will still post positive numbers in 2020, with rebounds anticipated in 2021 (Table 2). The situation on the ground is rapidly evolving and actual economic growth in 2020 will depend on the "shape" of the recovery curve. ${ }^{1}$

\begin{tabular}{|c|c|c|c|c|}
\hline & 2018 & 2019 & 2020 Forecast ${ }^{*}$ & 2021 Forecast* \\
\hline SE Asia & 5.1 & 4.4 & 1.0 & 4.7 \\
\hline Brunei & 0.1 & 3.9 & 2.0 & 3.0 \\
\hline Cambodia & 7.5 & 7.1 & 2.3 & 5.7 \\
\hline Indonesia & 5.2 & 5.0 & 2.5 & 5.0 \\
\hline Lao & 6.2 & 5.0 & 3.5 & 6.0 \\
\hline Malaysia & 4.7 & 4.3 & 0.5 & 5.5 \\
\hline Myanmar & 6.4 & 6.8 & 4.2 & 6.8 \\
\hline Philippines & 6.2 & 5.9 & 2.0 & 6.5 \\
\hline Singapore & 3.4 & 0.7 & 0.2 & 2.0 \\
\hline Thailand & 4.2 & 2.4 & -4.8 & 2.5 \\
\hline Vietnam & 7.1 & 7.0 & 4.8 & 6.8 \\
\hline
\end{tabular}

${ }^{*}$ Forecasts from Asian Development Bank (ADB)

Source: Adapted from Searight (2020)

SE Asia has been one of the fastest growing regions in the world over the last two decades, with annual rates averaging 5\%-6\% since 2000 (IEA 2020a); however, several of the industries behind that growth are highly susceptible to the current state of economic distress. Global demand for manufactured goods, which comprise between $16 \%-70 \%$ of GDP in countries such as Vietnam, Cambodia, Malaysia, and Thailand, is falling off. Tourism, another major contributor to GDP in the region, has all but stopped. SE Asia may not see rapid recovery in the manufacturing sector as demand for goods in the Americas, Europe, and other regions has been impacted by the pandemic response. Moreover, international capital has fled the region amid market turmoil. This reaction will have impacts across the financial landscape, from currency stability, to sovereign debt to corporate finance to renewable energy project finance (Searight 2020; World Bank 2020b). Economic contraction in the region also has implications for poverty in the region. While SE Asia has generally seen rising incomes and living standards over the last two decades, income inequality remains high in many countries. The COVID-19 pandemic threatens to erase some of these wealth gains, reverse this trend for vulnerable populations, and make it harder for many to find a pathway out of poverty (World Bank 2020d).

\footnotetext{
${ }^{1}$ Analysts have posited several recovery curve "shapes," from "V" to " $Z$ " to "U". This article from the Brookings Institution offers an overview of the factors behind and implications of each shape (Sheiner and Yilla 2020).
} 


\section{Power Sector Vulnerabilities}

Power sector vulnerabilities are weaknesses in infrastructure, processes, and systems, or the susceptibility of the sector to various natural, technological, or human-caused threats. The economic impacts of COVID-19 are exposing, and sometimes worsening, the existing power sector vulnerabilities in SE Asian countries, which can in turn imperil the safety, reliability, and sustainability of the region's power systems. This section provides a nonexhaustive list of five such vulnerabilities.

\subsection{Increasing Severity and Frequency of Natural Threats}

Worldwide, both the frequency and resulting cost of disasters are increasing. The two highest loss years in recorded history (both in terms of insured losses and overall economic losses) were within the last 10 years, and the entire decade between 2009-2019 was the costliest on record (Insurance Information Institute and Munich Re 2020). SE Asia, in particular, is among the world's most vulnerable regions to climate change-related threats (such as increasing temperatures, prolonged drought, changing precipitation patterns, and others). It is also prone to other catastrophic events such as earthquakes and tsunamis. From 2012 to 2018, SE Asia experienced approximately 1,380 natural disasters (Figure 1) (AHA Centre 2020). Due to the losses from these disasters, countries may frequently be in a position of allocating resources to response and recovery, often at the expense of other investments. This makes pandemics, such as COVID-19, a compounding threat.

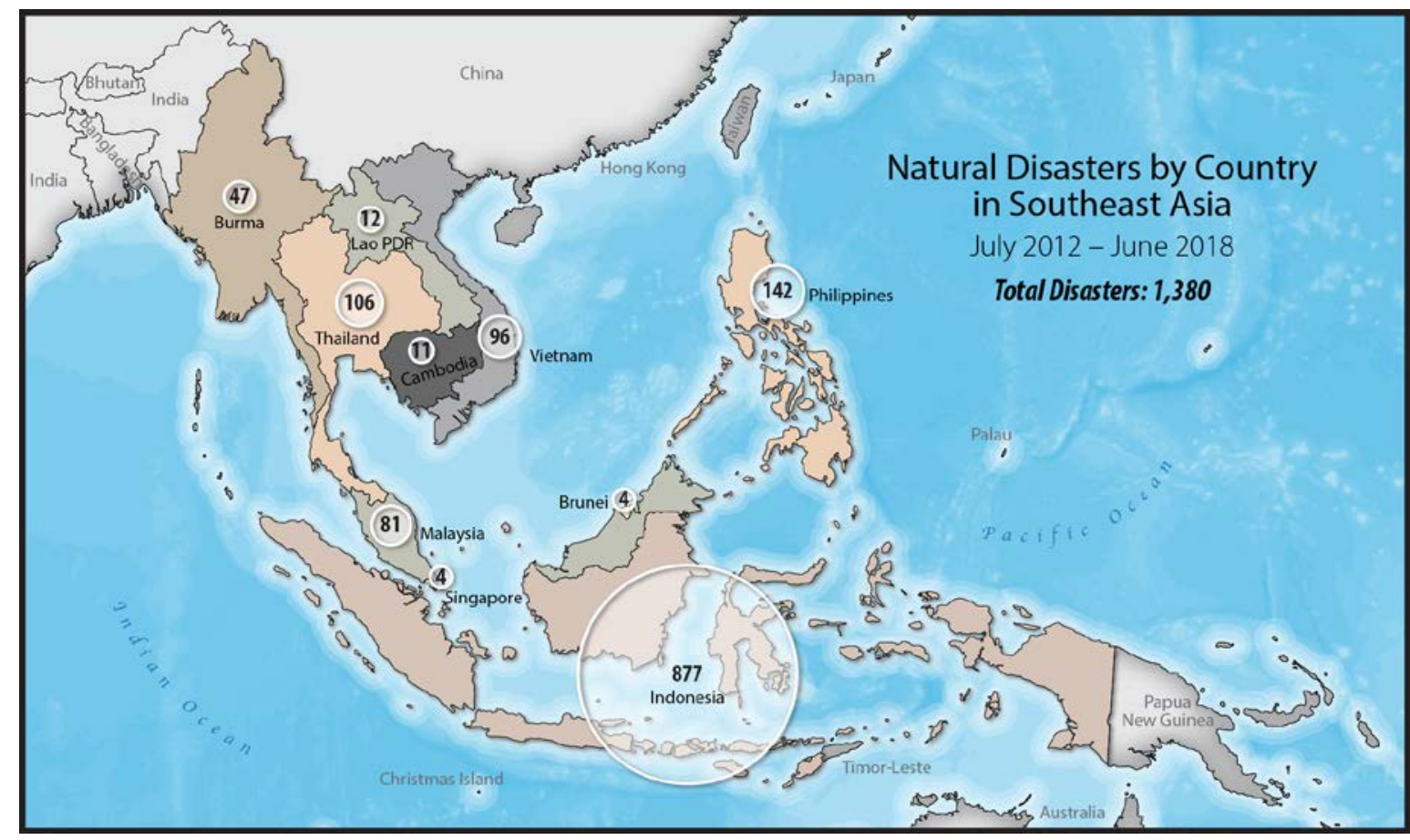

Figure 1. Total reported natural disasters reported in SE Asia from July 2012 to June 2018 (disasters include earthquakes, volcano eruptions, and hydrometeorological events such as flooding and landslides)

Source: NREL, adapted from original image from the ASEAN Coordinating Centre for Humanitarian Assistance on Disaster Management (AHA Centre) (2020).

\subsection{Power Sector Financial Health}

SE Asian countries have diverse approaches to the organization of their power sector. The Philippines and Singapore have restructured markets where generation and transmission have been unbundled from distribution and retail sales. ${ }^{2}$ Other countries have various levels of vertical integration, controlling much of the value chain

\footnotetext{
${ }^{2}$ In restructured markets, utilities are largely divested of generation and transmission asset ownership, are not responsible for the operation of the high-voltage transmission system or the wholesale market, and do not have balancing authority beyond their feeder networks, among other things. Only two countries in SE Asia - the Philippines and Singapore- have restructured markets.
} 
between generation and sale of electricity to customers, though several are currently undergoing reorganization. All countries in the region allow some form of private investment in generation. Figure 2 displays the various power sector organizations of select countries in SE Asia, as well as their pre-COVID-19 pandemic overall financial health metrics of project bankability (i.e., ability to attract investment capital), access to financing and cost of capital (a measure of corporate risk).

\begin{tabular}{|c|c|c|c|c|}
\hline Market & Power-Sector Organization & $\begin{array}{l}\text { Financial } \\
\text { Health of } \\
\text { the System }\end{array}$ & $\begin{array}{c}\text { Project } \\
\text { Bankability }\end{array}$ & $\begin{array}{l}\text { Financing } \\
\text { and Cost } \\
\text { of Capital }\end{array}$ \\
\hline Indonesia & $\begin{array}{l}\text { State-owned single buyer with IPPs; utility- } \\
\text { owned grid with retail regulation. }\end{array}$ & & & \\
\hline Malaysia & $\begin{array}{l}\text { Regulated single buyers with IPPS; utility- } \\
\text { owned grid with retail regulation. }\end{array}$ & & & \\
\hline Philippines & $\begin{array}{l}\text { Wholesale market with IPPs; partial retail } \\
\text { competition and grid unbundling. }\end{array}$ & & & \\
\hline Singapore & $\begin{array}{l}\text { Wholesale market with IPPs; retail competition } \\
\text { and grid unbundling. }\end{array}$ & & & \\
\hline Thailand & $\begin{array}{l}\text { State-owned single buyer with IPPs; utility- } \\
\text { owned grid with retail regulation. }\end{array}$ & & & \\
\hline Viet Nam & $\begin{array}{l}\text { State-owned single buyer with IPPs; utility- } \\
\text { owned grid with retail regulation }\end{array}$ & & & \\
\hline $\begin{array}{c}\text { Other } \\
\text { (Cambodia, Lao } \\
\text { PDR, Myanmar) }\end{array}$ & $\begin{array}{l}\text { State-owned single buyer with IPPs; utility- } \\
\text { owned grid with retail regulation. }\end{array}$ & & & \\
\hline $\begin{array}{l}\text { Low } 1 \\
\text { factor }\end{array}$ & $\begin{array}{c}\text { Potential risk } \\
\text { factor/barrier for } \\
\text { investment }\end{array}$ & \multicolumn{3}{|c|}{$\begin{array}{l}\text { High potential risk } \\
\text { factor/barrier for } \\
\text { investment }\end{array}$} \\
\hline
\end{tabular}

Figure 2. Financial conditions of select SE Asian power sectors

Source: Adapted from IEA (2019b) Southeast Asia Energy Outlook 2019. All rights reserved.

Several SE Asian utilities (regardless of public or private ownership) struggle with cost recovery. Complicating this is the fact that rates are already high relative to income in some countries (IEA 2019b). This results in a cost to the state, as revenue shortfalls are often covered by government subsidies. Additionally, utilities that struggle to recover costs will see negative impacts to their credit rating, which makes it difficult for them to borrow at favorable rates in debt markets.

Before the COVID-19 pandemic, some countries had difficulties making needed investments in operations, maintenance, and infrastructure to meet growing demand, improve reliability, and expand electricity access (IEA 2019b). This baseline financial condition constrains a country's ability to invest in and implement solutions needed to improve adaptive capacity, especially in the present-day pandemic environment.

\subsection{Fuel Mix and Fossil Fuel Reliance}

Over $80 \%$ of electricity production in SE Asia is from fossil-fuel based generation (see Figure 3). While coal, oil, and gas reserves exist in the region, they are not equally distributed across countries. With rapidly increasing regional energy demand and infrastructure build-out before COVID-19, SE Asia was poised, in aggregate, to become a net importer of fossil fuels (IEA 2019b). 


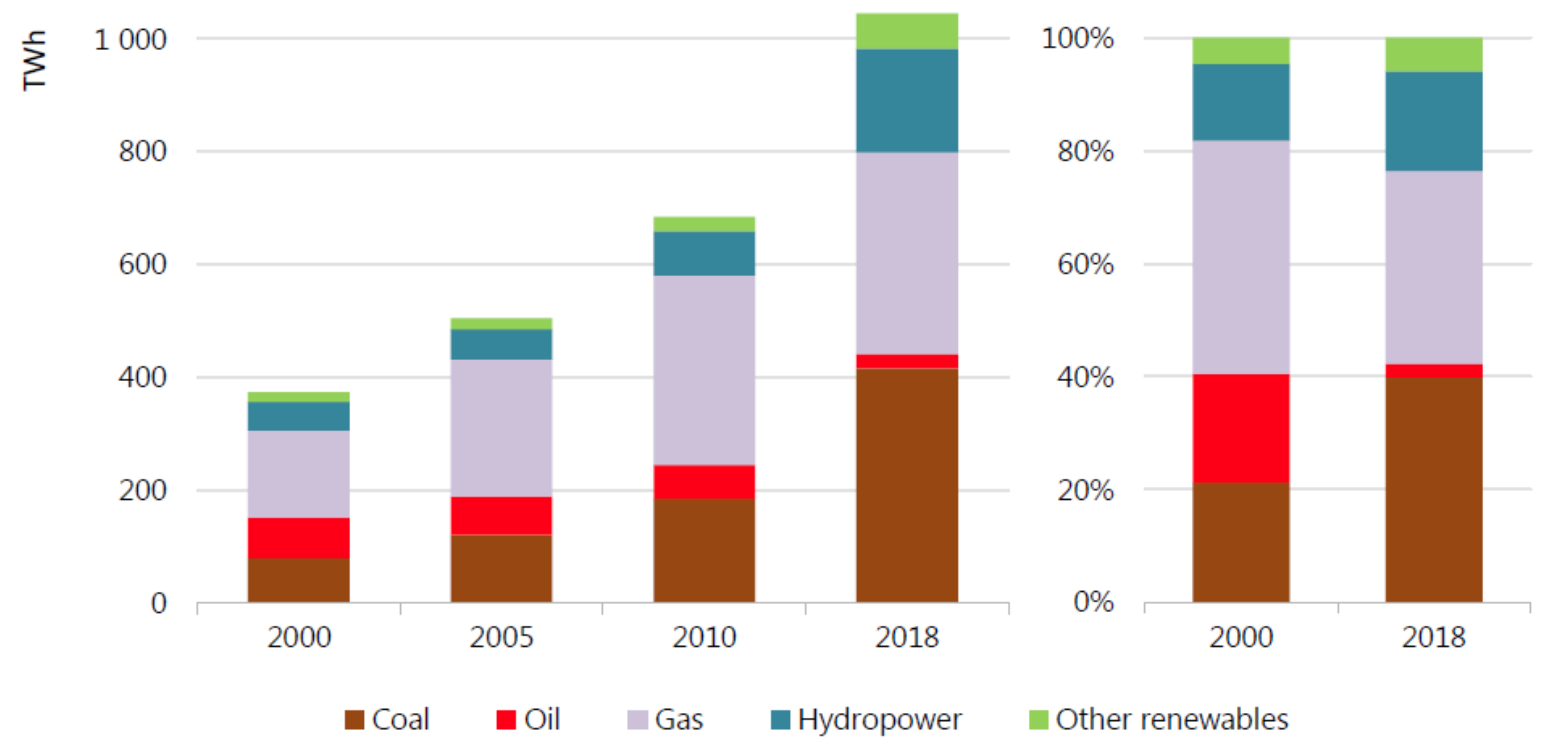

Figure 3. Power sector generation mix and share of the total regional output by fuel type in SE Asia 20002018

Note: TWh = terawatt-hours. "Other renewables" include solar photovoltaics, wind, geothermal, and modern use of bioenergy

Source: IEA (2019b) Southeast Asia Energy Outlook 2019. All rights reserved.

This reliance on fossil fuel-based thermal generation in SE Asia creates two vulnerabilities. First, some thermal assets may decrease power system flexibility, due to either technical or contractual limitations (see Section 4.2). This can disadvantage variable renewable energy penetration, which in turn complicates power sector decarbonization. Second, reliance on fossil fuels exposes countries in the region to economic shocks and supply chain complications in the oil and gas commodity markets. The price of oil is currently at record lows, which may be temporarily beneficial for electricity prices and IPP profit margins; however, any import disruptions resulting from restrictions on cross-border trading, or other supply chain obstacles, may impact local price and availability - ultimately damaging power sector operational integrity. Further, increased fuel imports in the region may push some SE Asian countries into trade deficits (IEA 2019b). Accordingly, high fuel subsidies in several countries means increased financial strain on national governments, which currently may need to focus resources to fund emergency economic stimulus and relief policies.

\subsection{Growing Energy Demand}

Before the pandemic, SE Asia's electricity demand was experiencing some of the fastest growth in the world (averaging 6\% per year) (IEA 2019b). This was due to increasing industrialization, urbanization, population growth, rising incomes, and extensive electrification goals, among other factors. Space cooling is the fastestgrowing energy end-use in SE Asia. Pre-pandemic projections by the International Energy Agency identified cooling as responsible for $30 \%$ of peak electricity demand for 2040 , requiring around $200 \mathrm{GW}$ of additional generation capacity in the region (IEA 2019c).

Analysts estimate that the power generating capacity in SE Asia will need to double by 2035 to accommodate the growing demand, requiring an investment of $\$ 500$ billion in generation assets alone (Wood Mackenzie 2017).

Creditworthiness, the policy and regulatory environment, project bankability, and overall economic health will all play a role in ensuring the necessary public and private financial flows continue to allow for power sector buildout. The source of finance is important, as China is eager to provide loans through its Belt and Road Initiative, potentially jeopardizing energy sector sovereignty in SE Asian countries if debt defaults lead to foreign appropriation of energy sector assets (Ibrahim 2020). 


\subsection{Air Quality and Pollution}

Fossil fuel combustion for electricity generation, transportation, and industry are major contributors to air quality concerns in SE Asia, a region that carries one of the highest global air pollution burdens (WHO 2020a). Coal combustion can be particularly polluting, with toxic emissions of mercury, lead, nitrogen oxides, sulfur oxides, ash (particulates), and carbon dioxide. The WHO estimates that the Western Pacific region experienced 2.4 million premature deaths attributable to air pollution in 2016 (Nery 2018). Air pollutants pose grave health consequences that compound impacts from diseases such as COVID-19. SE Asia is also a region of rapidly growing greenhouse gas emissions, due to high economic growth rates and a heavy reliance on fossil fuels for power generation and transportation. By 2040, energy-related greenhouse gas emissions in the ASEAN region are expected to almost double to 2.3 billion metric tons (IEA 2017). Rising greenhouse gas emissions mean that power sectors in the region will endure increasing impacts from climate-related disasters that affect economic recovery in the face of disaster. 


\section{COVID-19 Impacts on the Power Sector}

The COVID-19 pandemic is unique among the range of threats encountered over the last century, and its specific impacts do not necessarily resemble those of other disasters. In the near term, the pandemic is causing demand shocks, workforce impacts, supply chain complications, and a global, economic contraction with long-term consequences as yet unknown. In contrast, with natural disasters the principal impacts are more acute. These include infrastructure destruction, displaced populations, and often localized economic impact; however, the longterm response to both of these threats - pandemics and destructive forces of nature - requires similar approaches to building short-term and long-term resilience that prepare power sectors for safe and reliable operation during times of disruption.

This section reviews the observed, early-stage impacts of the pandemic and the various lockdown measures on SE Asian power sectors. Associated with each of these impacts are a set of recovery responses and opportunities for policymakers, regulators, utilities, and other entities to emerge from this crisis with higher power system resilience. The impacts and corresponding responses and opportunities discussed in this section are summarized in Table 3.

Table 3. Impacts of COVID-19 to SE Asia Power Sector and Recovery Responses/Opportunities

Impacts

Power Demand: Pandemic responses have decreased overall electricity system demand, lowering commercial and industrial usage while increasing residential consumption-shifting and changing the shape of load curves. Residential utility bills have increased for much of the population, adding additional strain to consumer financial health that has been impacted by economic disruption.
Recovery Responses/Opportunities

Energy Efficiency: Increase residential enrollment in energy efficiency and demand-side management programs to reduce consumer bills and improve system reliability.

Utility Modernization: Transition utilities to adopt modern, digital, decentralized, and transactive technologies and processes.

Sector Reform: Consider measures to develop a more marketoriented power sector to reduce state obligations and subsidies.

Subsidy Reform: While fossil fuel prices are at historic lows, divert state support away from energy subsidies toward efficiency measures that will benefit consumers and toward immediate pandemic response needs.

\footnotetext{
Contracts and Investment: Decreasing demand has exposed inflexibility in the power purchase and fuel purchase contract structures of some utilities in the region, leading to overpayments for excess capacity.
}

Contract Restructuring/Renegotiation: Investigate restructuring obligations such that they are resilient to catastrophe situations, including pandemics, natural disasters, and economic shocks. Going forward, new contracts should also be structured to sustain such flexibility.

Air Quality and Emissions: Declining rates of fossil fuel combustion have shown temporary improvements in air quality and reductions in emissions and pollutants.

Coupling Air Quality with Renewable Energy Policies: Tie in air quality goals with renewable energy and alternative transportation stimulus measures to incentivize further reductions beyond the pandemic. Link air quality, emission regulations, and renewable energy deployment in future policies/statutes.

Energy Sector Workforce: Employees of system operators, utilities, and IPPs who are infected with COVID-19 (e.g., workers in control centers and network operations centers) could threaten critical system operation.
Worker Protection Programs: Develop regimes for worker safety and continuity of operations in pandemic environments such that the power sector can operate safely and reliably. Such programs should be adaptable to situations beyond just the pandemic (e.g., applicable for natural disasters and other disruptive events where worker safety and system operations are at risk). 


\subsection{Power Demand}

\subsubsection{Impacts}

The power sector is comprised of the entities along the value chain from electricity generation, to transmission, to distribution, to sale/purchase (Table 4). The impacts of COVID-19 on the power sector affect these entities in different ways, and not all impacts are the same across countries in the region.

For much of the region, electricity demand is undergoing several key changes: electricity consumption has dropped and largely shifted to largely to the residential sector, creating an overall change in the shape of daily load profiles. ${ }^{3}$ With many businesses temporarily closed, a slowdown in manufacturing, and school closures, commercial and industrial consumption has fallen significantly.

These changes have consequences for all entities along the electricity value chain. For IPPs, the sudden and unplanned reduction in demand can equate to less revenue (unless their facility is contracted under a "take-or-pay" power purchase agreement [PPA] - see Section 4.2). This could be particularly true for generators that only run during system peak events, and therefore are able to capture high wholesale prices when the supply of electricity is temporarily limited. Uncertain revenue impacts IPP debt service and operating expenditures such as planned maintenance. It also may affect generator investments going forward, impacting the development, construction, and maintenance of energy projects (see Section 5).

\begin{tabular}{|c|c|c|}
\hline & Segment & Entities \\
\hline & Generation & IPPs, Utilities \\
\hline & $\begin{array}{l}\text { System Operations and } \\
\text { Transmission }\end{array}$ & $\begin{array}{l}\text { System Operators (in } \\
\text { restructured markets), } \\
\text { Utilities }\end{array}$ \\
\hline & $\begin{array}{l}\text { Market Operation (in } \\
\text { restructured markets) }\end{array}$ & $\begin{array}{l}\text { System Operators, } \\
\text { Market Operators }\end{array}$ \\
\hline & Distribution & Utilities \\
\hline & Retail Sales & $\begin{array}{c}\text { Utilities/Retail Service } \\
\text { Providers* }\end{array}$ \\
\hline & Consumption & Consumers/Ratepayers \\
\hline
\end{tabular}

${ }^{*}$ Only Singapore has full retail competition in its power sector. These entities will not be discussed in this section.

Decreasing demand and shifting load curves also affect transmission system operation. Facing a potential overcapacity situation, system operators have had to recalibrate their short-term forecasts (two to three years) and reevaluate their infrastructure planning to respond to the conditions in the marketplace. In countries with high transmission congestion and where demand growth is outpacing infrastructural buildout, the pandemic could delay the financing and construction of new assets that may improve system reliability and increase energy access. On the other hand, lower system demand during the pandemic can temporarily reduce transmission congestion issues (though with increased residential demand, utilities may see congestion at the distribution level). Wholesale market operators (if separate from the system operator) have had to deal with the effects of rapid price declines, market distortions, and arbitrating revenue shortfalls for distribution among market participants.

\footnotetext{
${ }^{3}$ Assessing whether demand has "dropped" during the pandemic will depend on the baseline that this demand is measured against. While many countries are seeing a drop in demand relative to the same period in 2019 (i.e., year-over-year), others may be seeing a drop relative to forecasted demand (i.e., the demand growth anticipated before the pandemic was not realized, even if overall demand has remained relatively steady). Regardless of the baseline comparison, it is generally the case that demand in every country in SE Asia has been negatively impacted by the pandemic and the ensuing lockdowns.
} 
For utilities, falling demand could mean several things, depending on their roles in the value chain. In markets where utilities are vertically integrated, from generation to sales, they face the issues of the all the entities discussed above. On the distribution side, higher residential demand is causing greater equipment stress on the lower-voltage network, as well as revenue reductions from the loss of high-volume customers in the commercial and industrial rate classes.

Residential demand has increased (especially from air conditioning loads), but in most countries it has been insufficient to offset decreased commercial load. For example, according to the Philippines Department of Energy, demand in the interconnected Luzon and Visayas grids has dropped by 30\% (Rivera 2020). Malaysia has seen a roughly $23 \%$ drop in demand from the period its lockdown began on March $18^{\text {th }}$ through late April (Wood Mackenzie 2020). In Singapore, systemwide demand dropped 8\% during the period from March 23 to April 25 (Wood Mackenzie 2020). Figure 4 illustrates how the country's "Circuit Breaker" response to the COVID-19 pandemic on April 7 reduced systemwide electricity demand over the course of a single day (compared to 2019 demand). The figure shows the entire week of April 6 to April 13, with 2020 demand (yellow line) dropping well below 2019 demand (grey line) for the same period.

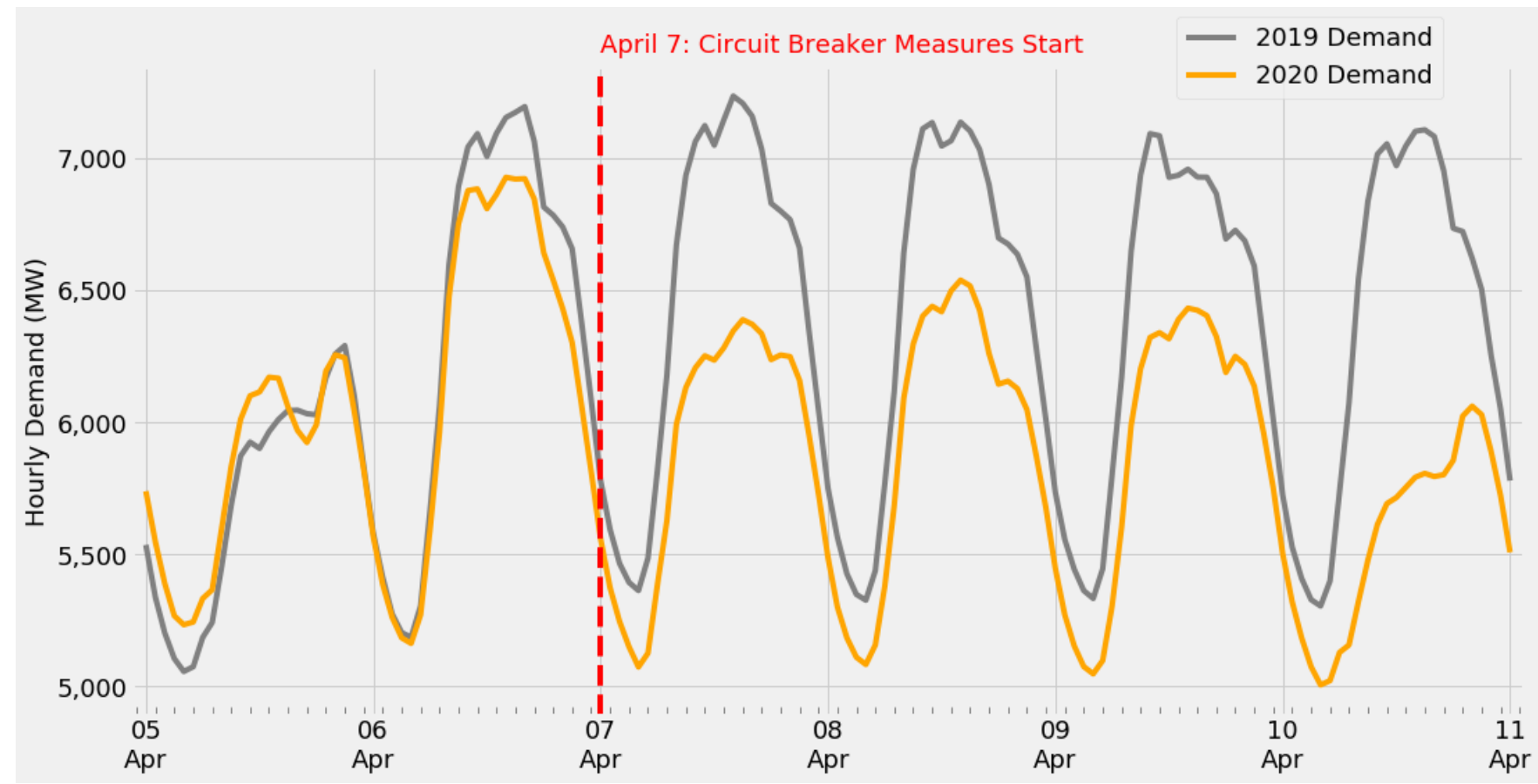

Figure 4. Singapore systemwide electricity demand during the second week of April in 2019 and 2020

Note: The Circuit Breaker Measures in Singapore consisted of a set of elevated safe distancing measures in Singapore (Singapore Ministry of Health 2020). See Table 1 for additional details.

Source: Generated based on information from Publications and Statistics: Half-hourly System Demand Data accessed on May 30, 2020 from Singapore Energy Market Authority (2020), which is made available under the terms of the Singapore Open Data License version $1.0 \mathrm{https} / /$ www.ema.gov.sg/Terms_of_use.aspx.

As the region heads into its notoriously hot summer period, cooling loads - which comprise a significant portion of building electricity usage in many SE Asian power sectors (IEA 2018) - are beginning to dominate the electricity system; however, as most of this demand is composed of distributed air conditioning units at individual dwellings (as opposed to the central units in many commercial facilities), the efficiency of servicing cooling load has dropped considerably. This may increase demand at potentially vulnerable low-voltage portions of the grid (S\&P Global Platts 2020). 


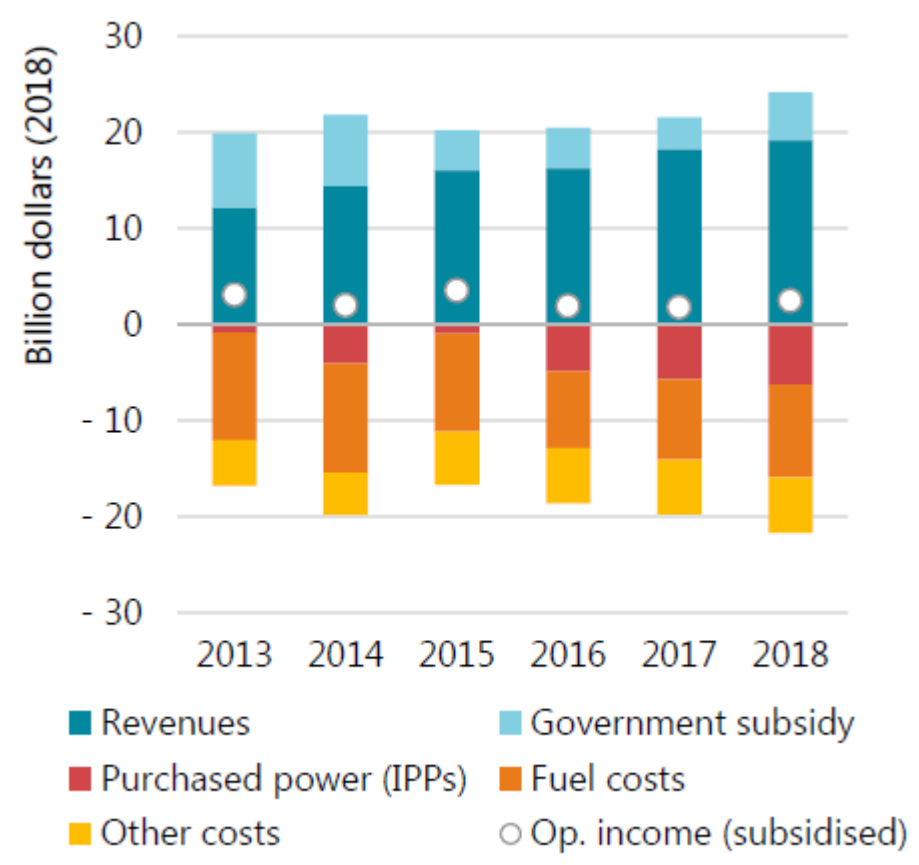

\section{Figure 5. Drivers of PLN's operating income in U.S. dollars, 2013-2018}

Source: IEA (2019a) Southeast Asia Energy Outlook 2019. All rights reserved.

Declining electricity demand also means that utilities are not recovering costs on their rate-based infrastructure investments as planned. Since cost recovery is already a challenge in some SE Asian countries, the shortfall between total cash flow from rate collection (operating revenue) and the revenue requirement (operating costs + regulated return) for the rate base is often filled by government subsidies (IEA 2019b). For example, Indonesia's state-owned utility Perusahaan Listrik Negara (PLN) requires a government subsidy to lift operating income into the black each year (Figure 5). This financial obligation on the government can hinder its ability to make productive investments elsewhere in its economy, especially for COVID-19 related stimulus measures to combat economic contraction.

When utilities are unable to meet their revenue requirement with sales under its tariff structure, one recourse is to raise rates, which must be approved by the regulator. This can place financial strain on consumers and/or ratepayers, particularly those of low-moderate income for whom electricity purchases take up a larger share of total earnings. If the electricity rates of countries in the region do rise in the future as a result of utility revenue shortfalls, this could prolong the financial burden of many households that are already paying higher energy bills because of stay-at-home orders. Another recourse is for utilities to cut costs. This could create reliability issues in the future as planned maintenance, capital investment, and other such expenditures are reduced or eliminated.

Some countries have made ratepayer relief a part of their pandemic response. For example, Thailand's stateowned Metropolitan Electricity Authority and Provincial Electricity Authority, adopted a suite of measures to reduce the energy burden on consumers, including bill reductions of $3 \%$ across all tariff classes, bill payment grace periods, refunding meter deposits for residential and small business users, and provision of free power to users with power meters of no more than five amps (Bangkok Post 2020). Additionally, the Energy Regulatory Commission of Thailand provided a temporary residential customer electricity bill reduction program that provides a 30\%-50\% discount based on energy consumption. On the commercial and industrial side, Malaysia provided for a $15 \%$ discount on electricity bills for six identified business types (hotel operators, travel and tourism, shopping facilities, convention centers, theme parks, and local airline offices) as well as a 2\% discount for other business types and agricultural and industrial customers. Both discounts end in September (Chaturvedi and Gaba 2020). It is unclear how these rate-payer relief measures will be funded given current utility revenue shortfalls and constraints on public budgets. 


\subsubsection{Opportunities and Recovery Responses}

- Energy Efficiency Energy efficiency measures, such as cooling equipment performance standards, building codes, and demand-side programs, can play an important part in the near-term recovery needs for power systems and consumers across the region. As people will be spending more time at home and indoors, cooling demand will continue to rise, placing additional stress on power systems to meet this load at the hottest part of the day, while keeping the vulnerable population safe. Improving cooling efficiency has the potential to reduce peak demand under normal conditions, as well as save consumers on their mounting electricity bills during the pandemic. Over the longer term, energy efficiency measures will improve system reliability, enhance integration of renewable energy, and defer expensive system upgrades, while also contributing to the decarbonization of the electricity system. With customers at home, utilities have an opportunity to capture their attention and promote energy efficient technologies and programs through social media and other established channels. Deploying efficiency measures and demand response programs in the commercial and industrial sector could be undertaken as part of immediate stimulus plans, while much of the commercial

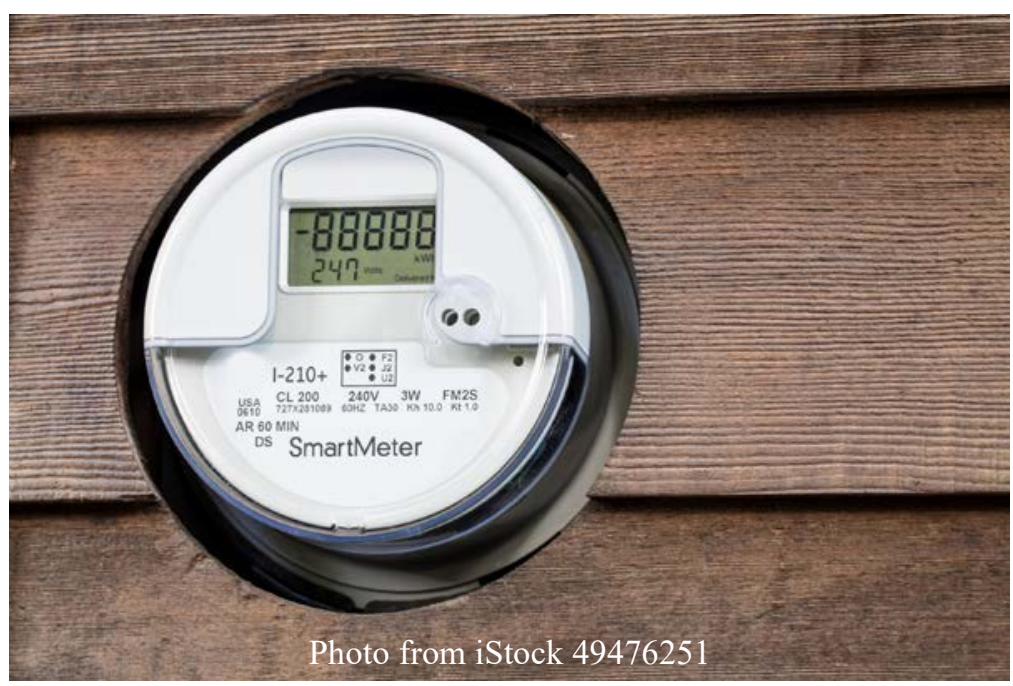
building stock sits idle.

- Utility Modernization The COVID-19 pandemic could force further reconsideration of the traditional utility business model in the region (i.e., the regulated monopoly serving electricity from large centralized plants and earning cost recovery plus a regulated return). The proliferation of distributed technologies (solar, storage, electric vehicles, dispatchable load, and others) is challenging traditional utility ratemaking and customer service practices. The pandemic and consequent economic fallout could give utilities, regulators, and policymakers the opportunity to begin implementing measures to modernize the traditional model. Such measures could include regulatory mandates to invest in digital infrastructure (e.g., bidirectional smart meters) or developing new products and services to better serve ratepayers at a time when customer empowerment and "prosuming" are growing. ${ }^{4}$ Simple and direct measures could be undertaken now, such as working to enable electronic bill payments (where not already common) to facilitate social distancing measures. Over the medium-term, larger capital investments in telemetry infrastructure, supervisory, control, data acquisition systems, and distributed energy resources could simultaneously provide grid services, improve operations, drive customer satisfaction, and ultimately reduce costs. As the pandemic eases, regulators and policymakers may consider adopting performance-based ratemaking regulations and other structural incentives to incentivize utilities to accomplish such priorities, where applicable (Littell et al. 2018).

- Sector Reform: Government stimulus and economic relief responses to the pandemic have stressed national budgets and forced reconsideration of where states have traditionally invested their resources. Countries in the region are at different stages of market transition and sector reform. For example, Vietnam plans to launch a wholesale electricity market by 2023 , and in Thailand, a dialogue is emerging over whether the government can continue to support a state-owned single-buyer utility in the wake of their recent expenditures (Sutabutr 2020). A movement to a modern, market-based electricity system could provide relief to state budgets over time, but it could also benefit consumers by enabling a system for price transparency and competition. This could also include modification of current utility tariff regimes to make them more cost-reflective.

- Subsidy Reform: Restructuring of fossil fuel subsidies could help promote efficient resource usage, improve air quality, and level the playing field for domestic renewable energy development. Governments will have

\footnotetext{
${ }^{4}$ Prosumers are utility customers that both consume electricity and can generate their own using solar or another distributed generation device. For more on this topic and innovative utility products and services, see Lowder, Logan, and Chen (2019).
} 
the opportunity to revisit their fossil fuel subsidy regimes as prices for oil and natural gas fall, and public spending is largely redirected to managing the economic fallout from the COVID-19 pandemic. Subsidy funds could be used for price relief stimulus measures, and in the long-term redirected toward other policy goals, such as poverty alleviation and energy access (World Bank 2020c).

\subsection{Contracts and Investment}

\subsubsection{Impacts}

In several SE Asian power sectors with vertically integrated utilities, contractual purchases of electricity from IPPs are allowable by law. These contracts commonly take the form of PPAs that stipulate the sale of energy on a unit of currency per unit of electricity basis (e.g., USD/MWh). These contracts can contain clauses known as "take-or-pay" provisions, where the offtaker (the purchaser of the power) is obligated to buy all the electricity produced by the generator, sometimes with a floor and/or a ceiling. These provisions can be beneficial to IPPs and reduce the financial risk of their projects by making revenue streams stable and predictable (and thereby reducing the project's cost of energy). These protections also create a climate of project bankability which allows for higher

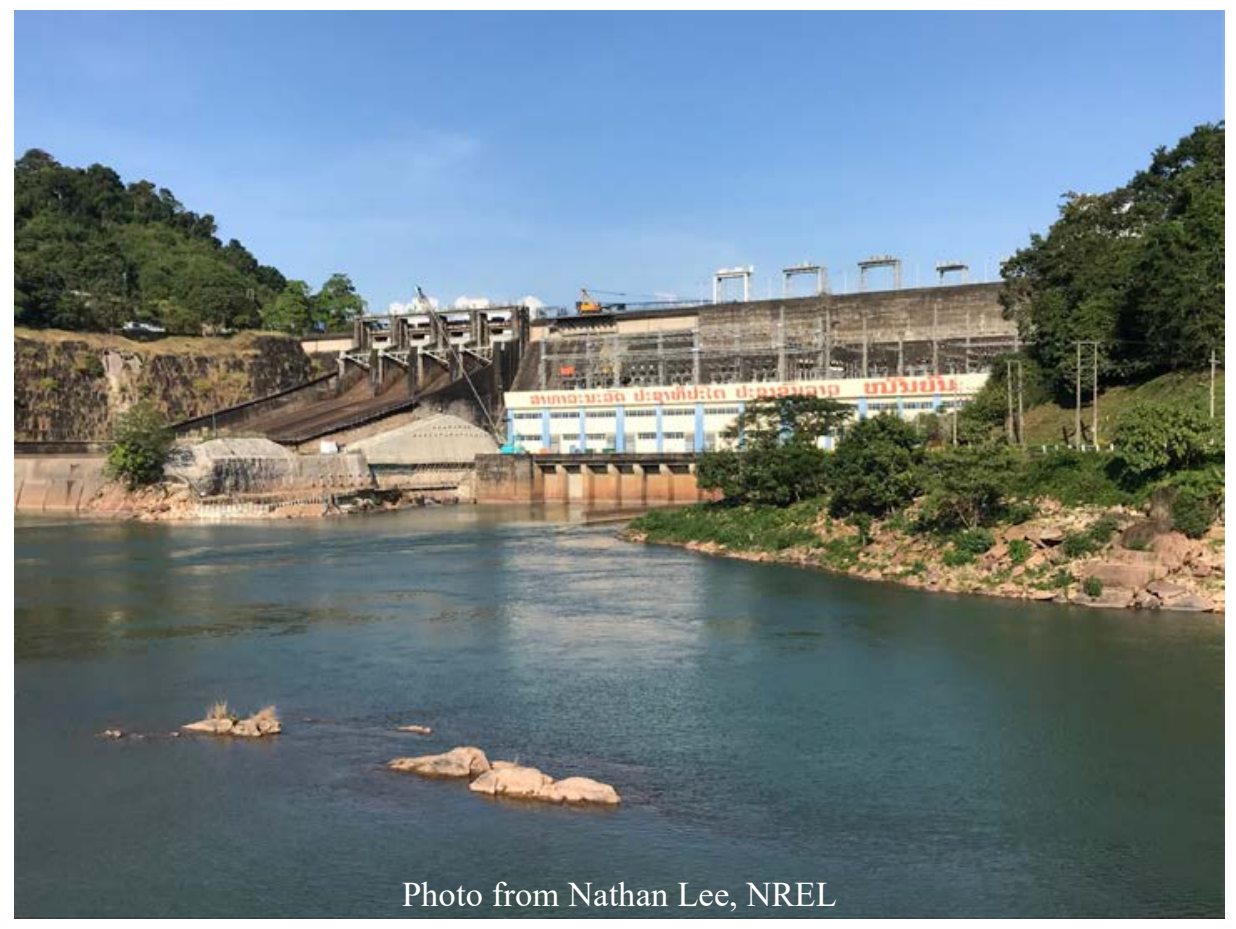
capital flows and lower cost of capital; however, they can also bind utilities to payments that may, over the length of the contract, exceed what the utility could capture on the market (a cost which ultimately is passed on to consumers).

Indonesia's PLN is notable in SE Asia for its quantity of takeor-pay and capacity payment contractual obligations with thermal (mostly coal) generators; however, it is not unique in the region. In 2015, President Joko Widodo released a plan to grow the country's generation capacity by $35 \mathrm{GW}$ by 2019 (a near doubling) to meet the country's expanding energy needs and electrify a greater share of the population

(Ernst \& Young Global 2014). ${ }^{5}$ This massive capacity expansion was largely accomplished with PPA contracts between PLN and international IPPs that have locked the utility into fixed prices for much of its purchased electricity, leading to oversupply issues in several parts of the island nation. This oversupply is exacerbated by not only a pipeline of planned projects for which the utility has already contracted, but also the sudden and swift impacts of COVID-19 on demand. PLN is now in a situation where it must pay for the capacity of this generation portfolio, even when it does not need the power from a planning reserve margin perspective (Melissa Brown 2020). Similar examples of this situation can be found in Thailand and elsewhere in SE Asia.

Indonesia may be able to restructure IPP contracts through invocation of force majeure clauses, a contractual provision that frees parties in the agreement from liability when they are faced with an extraordinary circumstance such as a war or an "act of God" (under which a global pandemic would likely fall) (Wiazowski and Zeyl 2020). Meralco, an electric distribution utility in the Philippines, has invoked force majeure in several of its power supply agreements during the country's period of Enhanced Community Quarantine. This has reduced expenses to the utility, savings which can be passed on in the form of discounted utility bills for consumers (MERALCO

${ }^{5}$ The year 2019 has since been pushed out to 2024-2025 as only about $10 \%$ of this target had been achieved by the second half of 2019 (Sulaiman 2019). 
2020b). Force majeure and other contractual provisions may also be invoked to delay the development of energy projects, as well as to prevent operational must-run projects from selling unneeded electricity. In Thailand, for example, depressed demand and increased reserve capacity resulting from the COVID-19 response, has made the Electricity Generating Authority of Thailand consider delaying the commercial operation dates of small power producer plants with PPAs due to existing overcapacity (Praiwan 2020). Project developers are also invoking force majeure in instances where they cannot meet their contractual obligations (such as in the case of delays from the inability to obtain necessary materials or social distance restrictions on construction).

\subsubsection{Opportunities and Recovery Responses}

The COVID-19 pandemic may meet the criteria for a force majeure event in many contracts and can thus be invoked as a reason to adjust terms. While this can provide some relief for inflexible contract structures, such as those in Indonesia and Thailand, buyers must exercise caution in restructuring, renegotiating, or exiting contracts entirely. To access reasonably priced capital on the international financial markets (e.g., through issuing bonds or equity shares), utilities must have a credit rating at or above "investment grade." Maintaining such a credit rating through a pandemic - especially for a utility with baseline vulnerabilities - can prove challenging, especially when contractual fidelity can be an important consideration for ratings agencies; however, given the extraordinary circumstances of the pandemic, some restructuring of obligations may be necessary to ensure the continued safe, reliable, and least-cost operation of the power system. Countries should look to ensuring PPA terms in the future that enable access to full generator flexibility, especially as more variable generation comes online.

\subsection{Air Quality and Emissions}

\subsubsection{Impacts}

Air pollution is a known risk factor for respiratory infection, and according to the Centers for Disease Control and Infection (CDC), populations with pre-existing respiratory and heart disease are at greater risk of complications from COVID-19 (CDC 2020). Recent research found a significant relationship between air quality and the COVID-19 infection in China (Zhu et al. 2020). Poor air quality and its related health impacts may place much of the population in the region at greater risk to current and future pandemic outbreaks. In the short term, lockdown measures across many countries have shown a temporary improvement in air quality due to decreased demand in the power sector and a reduction in transportation related fuel combustion (Sommer 2020). In Metro Manila, enhanced community quarantine measures caused a $45 \%$ reduction in nitrogen dioxide levels as a result of both a transportation slowdown and declining power demand (Suarez and Myllyvirta 2020). Cleaner air reduces burdens on the health care system, reduces life expectancy inequality, and eases financial hardship on individuals, companies, and the state, among other positive outcomes.

The International Energy Agency (IEA) predicts that this pandemic will prevent 2.6 billion metric tons of $\mathrm{CO}_{2}$ from being emitted into the atmosphere, or around $8 \%$ of annual emissions, the single largest reduction event in history (IEA 2020a). While this is significant, these types of reductions are required year after year to keep the global temperature increase below $1.5^{\circ} \mathrm{C}$. This temporary emissions slowdown will likely return to previous levels as economic activity rebounds.

\subsubsection{Opportunities and Recovery Responses}

While a temporary economic slowdown has reduced pollution, reopening is beginning to bring pollution levels back up to pre-lockdown levels. Policymakers and regulators can act to preserve pollution reduction by linking clean energy deployment and air quality improvements through future policies and regulations. They also have an opportunity to capture support for these measures as the public is quickly seeing the benefits of reduced pollution in their everyday lives. Additionally, as governments consider longer-term stimulus measures, beyond immediate economic response, they can tie together renewables, efficiency, air quality and alternative transportation, fossil fuel regulations, and economic goals into a national strategic priority, and set the stage for cross-cutting policies that can achieve co-benefits goals in each of these three areas. 


\subsection{Energy Sector Workforce}

\subsubsection{Impacts}

The energy sector workforce across the electricity value chain (see Table 4) is critical to keeping the lights on. From building and operating generation and transmission, to distribution line maintenance, to utility administration, workforce challenges abound in an environment of social distancing and quarantine. Energy projects across SE Asia are experiencing delays due to shutdowns, concerns for worker safety, and a slowdown in regulatory processes. For example, in the

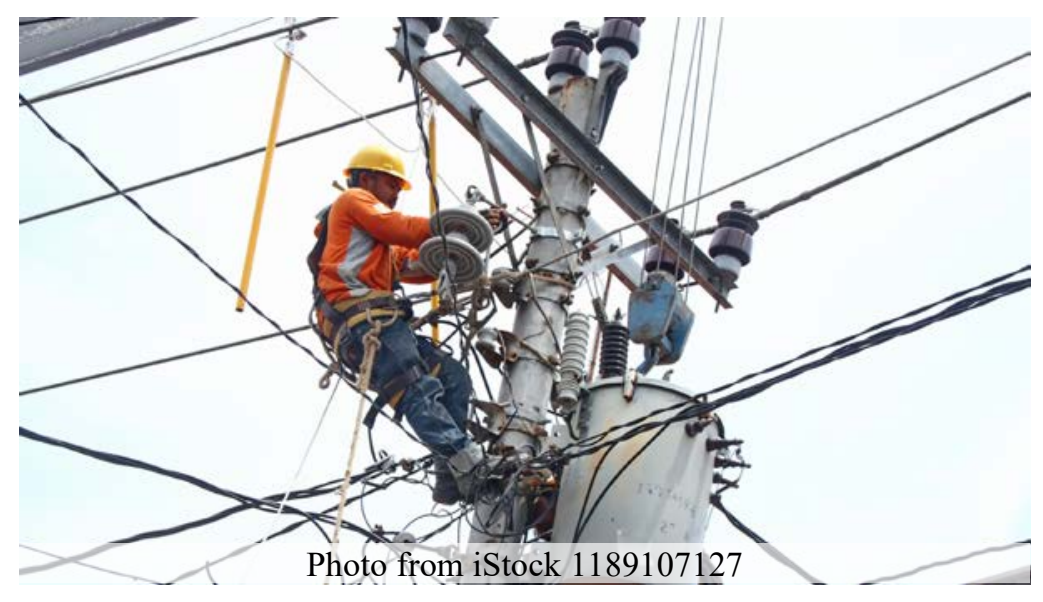
Lao PDR, the government has temporarily halted hydropower projects on the Mekong River (CNA 2020a). In the Philippines, without the ability to send out meter readers, the privately-owned utility Meralco cannot accurately determine energy usage to collect payments. Here, the utility is utilizing bill averages, which will be reconciled once workers are able to return to the field (MERALCO 2020a). The job of the system operator, maintaining a reliable supply of electricity $24 / 7$, requires skilled workers who perform this duty every hour of the day, every day of year. To ensure this can be done, the National Grid Corporation of the Philippines (NGCP), the system operator in the Philippines enacted a quarantine-related protocol to ensure system operators will not fall ill and will be able to continue providing this critical service. Likewise, Vietnam enacted strict quarantine measures to protect critical system operators and other workers.

\subsubsection{Opportunities and Recovery Responses}

To keep the power system running, grid and power plant operators must be on-site and sometimes in close contact with others in network operation centers and control rooms. Several system operators have implemented regimes to provide temporary housing for these workers on-site (to assist with quarantine measures), and social distancing/personal protection protocols for operators that are confined in close quarters. These have allowed continued operations during a time of lockdown and should be considered for codification into laws or regulations to keep essential power system workers protected. As has been evident in the meat processing industry in the United States, if a significant proportion of workers in any particular industry or supply chain node fall ill, supply shocks can ripple downstream and cause market failures. Even as the power system grapples with excess capacity, there is still the risk of blackouts and brownouts, power quality fluctuations, equipment damage, and other dangers.

The Electricity Subsector Coordinating Council—a U.S. organization dedicated to helping the electric power industry plan for and respond to national-level disasters - released a guide on workforce protection regimes that also preserve the power system operational integrity (ESCC 2020). This guide encapsulates best practices and lessons from across the United States electricity sector, including worker protection, supply chain issues, cybersecurity concerns, and other critical system operations areas. Utilities in SE Asia that do not already have these national-level sector response institutions or documents could benefit from developing their own. Also, existing or newly developed continuity-of-operations plans could be broadened to include pandemic-related responses.

In utilities with a large share of aging workforce reaching retirement, COVID-19 could present a threat, which may be connected to near-term risk of increased retirements as it seems to affect older populations with existing conditions more than younger populations. Utilities may consider training plans to better position themselves in response to loss of personnel and knowledge. 


\section{COVID-19 and the Clean Energy Transition ${ }^{6}$}

Renewable energy has quickly become the least-cost electricity resource in many markets worldwide, where auctions and highly competitive procurement environments have driven prices down year-over-year. In SE Asia, for example, a 2019 solar auction in Cambodia — the country's first ever - set a record low for SE Asia of $\$ 0.03877 / \mathrm{kWh}$ (ADB 2019). Overall, SE Asia has enormous renewable energy potential that can be feasibly developed, with potential solar photovoltaics capacity exceeding $41 \mathrm{TW}$ and potential wind capacity exceeding $1.8 \mathrm{TW}$ for a range of reasonable levelized cost of energy (Lee et al. 2019). Likewise, there is a huge untapped potential for energy efficiency in the region, which plays an important role in reducing overall and peak demand, enhancing system flexibility, and reducing the need to build more generation capacity.

Despite falling costs for renewable generation as well as concerns around air quality, emissions, and energy security, renewable energy investment and adoption has not kept pace with other growth areas such as GDP and fossil demand (see Figure 6). Today, non-hydro renewables account for roughly $6 \%$ of total regional power generation (IEA 2019b).

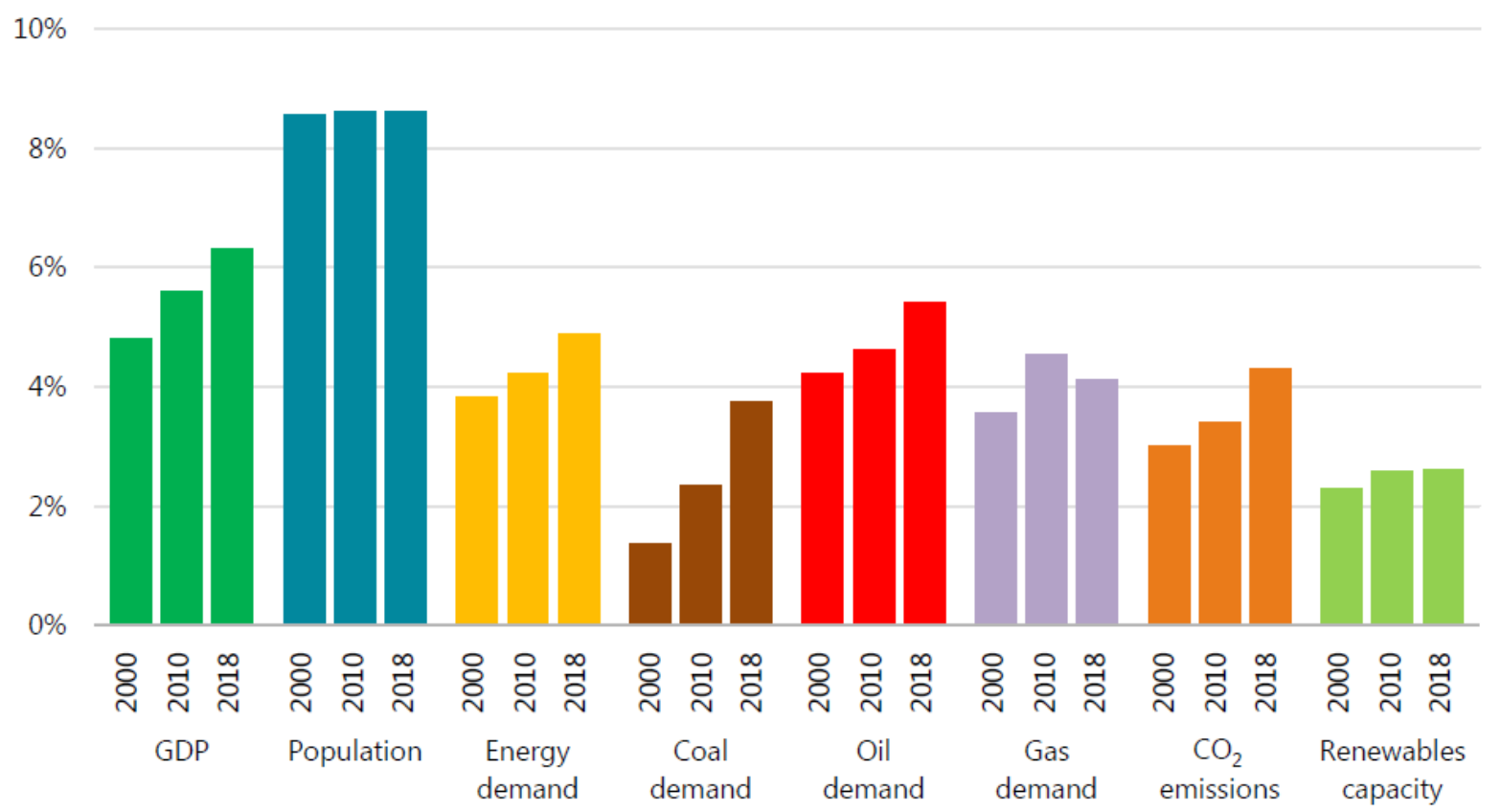

Figure 6. Share of global economic and energy indicators in SE Asia

Note: Vertical axis shows SE Asia share of global total. GDP = gross domestic product (\$2018, power purchasing parity); $\mathrm{CO}_{2}=$ carbon dioxide. Renewables includes solar, wind, hydropower, and bioenergy.

Source: IEA (2019b) Southeast Asia Energy Outlook 2019. All rights reserved.

Across SE Asia, countries have adopted renewable energy, energy efficiency, and greenhouse gas emission targets, yet deployment and investment varies greatly by country. Regionally, the Association of Southeast Asian Nations (ASEAN) has set a nonbinding target of 23\% renewable energy in their total primary energy supply 2025 (ACE and IRENA 2016).

Recent policy changes and stepped-up efforts from policymakers have lifted growth rates for non-hydro renewables in the region (IEA 2019b). Vietnam, for example, has installed 5.6 GW of solar through its feed-in tariff program, with an additional $900 \mathrm{MW}$ of wind generation, by the end of 2019. Thailand, an early mover on renewables in the region, saw nearly $5 \mathrm{GW}$ of cumulative wind and solar installations by the end of 2019 (Matt Brown and Heling 2020). Other SE Asian countries fall below these levels of penetration (e.g., Indonesia,

\footnotetext{
${ }^{6}$ We use the term "clean energy" to encompass the range of technologies in both the renewable energy and energy efficiency categories.
} 
Malaysia, and Philippines have a cumulative installed capacity of only $3 \mathrm{GW}$ of wind and solar between them) but are anticipated to see growth in their renewables capacity (Matt Brown and Heling 2020).

\subsection{Impacts}

The COVID-19 pandemic has impacted clean energy in the region, while also opening new opportunities:

- Renewable Energy Generation: Renewable energy project revenues have proven to be the most resilient generation resource during this pandemic, as these technologies are generally first in the merit order of dispatch (because they have no fuel costs) and because many are contracted by take-or-pay PPAs or covered by feed-in tariffs. In the first quarter of 2020, the IEA reported a global increase in renewable

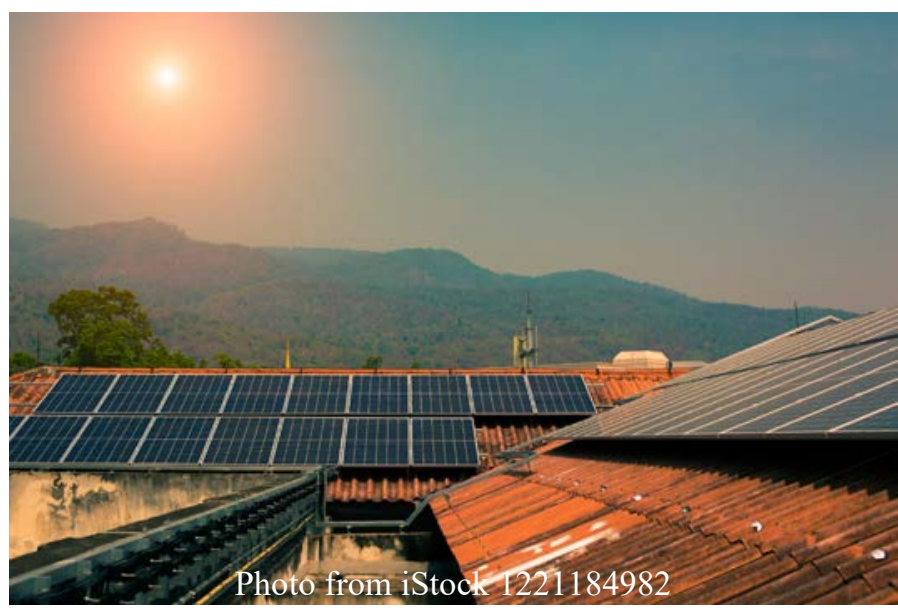
electricity generation by almost 3\% (IEA 2020a). Even when coupled with lower overall demand and the additional capacity coming online in the first quarter of 2020, SE Asian power grids are currently managing these increased penetrations of variable renewables (IEA 2020b).

- Project Development: Revenues from existing wind and solar projects (both utility-scale and distributed) have proven largely resilient to COVID-19 impacts; however, projects in the pipeline have experienced slowdowns due to supply chain disruption, regulatory delays, and workforce issues. Many of these projects will be delayed but will come online and are expected to rebound in 2021. Going forward, it is unclear what the uncertainty will mean for investors, and if investments may experience a slowdown in a time of economic downturn or if renewable energy investments may see a rebound in 2021 as some analysts have predicted (IEA 2020b).

- Supply Chain Disruption: China produces a significant portion of the world's solar panels, as well as many raw materials (e.g., steel for turbines and rare earth materials for batteries) that feed renewable energy technology supply chains (Baraniuk 2018; ClearWorld 2020). Renewable energy project developers that were completing their projects during this pandemic may have incurred additional costs and delays that could affect their anticipated returns or project milestones; however, even as these supply chain challenges start to let up, the pandemic experience has highlighted supply chain susceptibility to future shocks, including a COVID-19 resurgence in China or escalating trade tensions.

- Fossil Fuel Prices and Renewables Competitiveness: With a global economic slowdown, and the resulting fall in transportation and electricity demand, oil and natural gas prices have plunged. These low prices translate to reductions in the levelized cost of energy from existing oil and gas power generation plants. Currently, the levelized cost of energy from solar photovoltaics is competitive with combined cycle natural gas turbines in several SE Asian markets (where the regulatory structure permits their construction) and is anticipated to drop further over the next decade. If this temporary reduction leads to longer-term decreases in oil and gas prices compared to pre-COVID-19 levels, investment in these projects could hamper renewables deployment going forward.

\subsection{Clean Energy Opportunities and Recovery Responses}

While renewable energy policymaking may not be the center of attention, there are opportunities to couple national pandemic relief measures with those to improve the resilience and reduce the carbon intensity of the power sector (CNA 2020b).

- Public Sentiment: As many cities experience improvements in air quality, perhaps one of the most visible impacts of COVID-19 on the energy sector, the demand for clean energy continues to grow. Organizations such as IEA, World Resources Institute, and International Renewable Energy Agency are all calling for increased investment and a transition to renewables as part of a recovery plan that both protects the health and 
wellbeing of citizens while also providing energy to fuel economic growth. Power systems that are now operating at greater penetrations of renewable energy as a result of the pandemic may offer proof-of-concept that higher variability in the system is manageable.

- Business Continuity Planning: Changes in market realities for many clean energy businesses (e.g., workforce reductions, economic downturn) provide an opportunity to make business model pivots and explore new opportunities. Planning for business continuity during this and other times of disruption can protect project developers, technology service providers, and others from the worst effects of market turmoil while also driving innovation. As of this writing, assistance in this type of planning is available for some businesses in the clean energy space. For example, the Private Finance Advisory Network has launched a series of webinars, "virtual clinics," and one-on-one consultations with project developers to help them evaluate current strategy and identifying strategic measures to continue work in the pandemic environment (PFAN 2020).

- Clean Energy for Economic Recovery: There is an opportunity to tap into a clean energy transition as part of the recovery process as countries reopen for business and governments investigate longer term economic reform measures. In 2017, 12.3 million people were employed in renewable energy worldwide, which is expected to more than double to 25.6 million by 2050 (IRENA 2020). Clean energy can help create employment across global value chains and sectors, including manufacturing, finance, construction, and operations, maintenance. Moreover, clean energy draws on a diverse and inclusive employment pool, from unskilled labor all the way up to executive level positions. Investing in clean energy deployment as part of a broader effort to spur economy-wide job creation not only presents an economic development opportunity, it entails the co-benefits of decarbonization and air quality improvement, which themselves can contribute to health care savings, worker productivity, climate change impact reductions, and power sector resilience. These investments may be most effective in areas that are tried and true and have a legal basis with operating history (for example, extending feed-in tariff programs where they are currently active, or recalibrating them to effect greater stimulus). Finally, clean energy economic stimulus could also help drive technology innovation and further drive technology cost reductions. 


\section{Building Long-Term Energy Sector Resilience}

Power sector resilience means the ability to anticipate, prepare for, and adapt to changing conditions and withstand, respond to, and recover rapidly from disruptions to the power sector (Lee and Stout 2019). Resilience is much more than the power sector's typical view on "reliability", or a measure of whether a power system can provide regular, consistent power. Building long-term resilience requires holistic planning, robust policies, and the deployment of technical and institutional solutions at many levels across the power system. Responding to threats - whether pandemics or natural disasters - requires similar approaches to building resilience that prepare power sectors for safe and reliable operation during times of disruption.

COVID-19 represents a major disruption to power sectors across the world, exposing vulnerabilities in how these systems are planned, designed, and operated. It also represents a compounding threat in a region already experiencing impacts from other natural disasters. The pandemic is not the first, nor will it be the last, threat to the power systems of the region, and this highlights the need for long-term resilience considerations in system planning and operations.

\subsection{Resilient Power Sector Planning}

Planning is a fundamental exercise necessary for all power systems. Power systems require long lead times and large-scale investment to meet future energy demand while simultaneously ensuring the reliability, economics, and sustainability of supply. Power sector planning must constantly balance these considerations in an increasingly complex and rapidly changing world. To protect the power system from disruptions, both anticipated

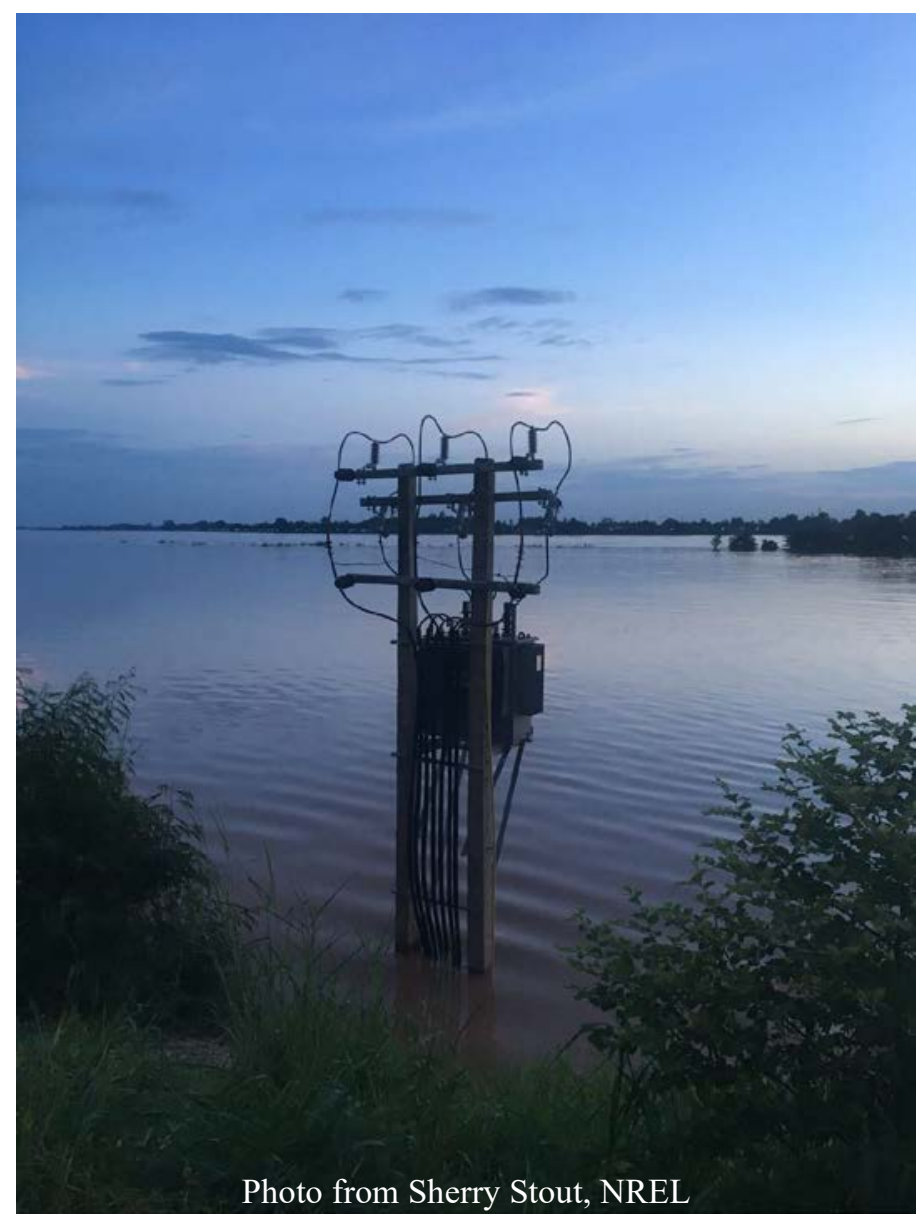
and unanticipated, resilience considerations must be built into capacity expansion, transmission build-out, and power system operation planning. Countries should assess the likelihood and severity of natural and human-caused threats to their power systems, identify vulnerabilities, determine risk, and implement solutions that improve the overall resilience of the sector to both acute and long-term threats (Lee and Stout 2019).

Resources such as the Resilient Energy Platform provide methodologies to undertake country-driven assessments that support resilience planning (Figure 7). ${ }^{7}$ Likewise, methods such as Integrated Resource and Resilience Planning are one approach to inclusive sectoral planning that seeks to minimize power system risks while ensuring reliable supply (Scheller and Chikkatur 2014; Bruguera, Hellmuth, and Man 2019). In SE Asia, the Lao PDR recently performed a stakeholder-inclusive power sector resilience planning process, led by the Ministry of Energy and Mines and supported by USAID (Stout et al. 2020). The Lao PDR, a country highly dependent on hydropower, is facing changes in precipitation patterns. Through their assessment, they determined several priority interventions, including supply diversification, which are being incorporated into their Integrated Resource and Resilience Planning process.

\footnotetext{
${ }^{7}$ To learn more about the USAID-NREL Partnership's Resilient Energy Platform, see: https://resilient-energy.org/.
} 


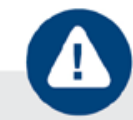

Identify Threats Identify the potential threats to the power sector and assign a likelihood score for each.

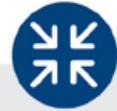

Define Impacts

Describe the effects that threats have on the power sector.

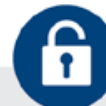

Assess Vulnerabilities Determine power sector vulnerabilities and assign a severity score for each.

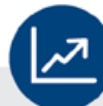

Calculate Risks Evaluate risk, which is the product of the threat likelihood and vulnerability severity score.
Develop Solutions Develop and prioritize resilience action plans based on impact, ability to implement, and cost.

Figure 7. Resilient energy planning process

Source: USAID-NREL Partnership (2020)

Another centrally important step is ensuring resilience enabling policies are in place before they are needed. These policies may dictate readiness actions, or even outline interconnection codes and standards that would enable system islanding in the case of a disaster event. In 2018, the Philippines Department of Energy released its energy resiliency policy, applying to all participants in the sector (Philippines DOE 2018). This policy requires all energy related companies to develop and implement Resilience Compliance Plans to ensure continuity of operations during disasters.

\subsection{Resilience of Critical Services}

In the face of a global pandemic or other threat, countries must ensure continuity of critical services, such as hospitals, sanitation, and emergency services. Knowing these critical load levels as well as which facilities/operations (cooling, for example is especially important for SE Asian countries) are prioritized for electrical service ahead of a disaster will ensure that the response is more coordinated and effective, which can save lives.

For critical facilities, technologies and practices such as microgrids with storage can provide power 24/7 in the case of prolonged outages. The Sendai microgrid in Japan, a microgrid on the teaching hospital of Tohuku Fukushi University, was designed to ensure power supply to this critical facility in case of power outages. During the 2011 earthquake and subsequent tsunami, this microgrid (comprised of natural gas, solar, and storage technologies) was able to supply heat and power to the facility for two days during the ensuing blackout (LBNL 2020).

\subsection{Financial Resilience}

Power sector operators need capital reserves and other financial resources to effectively respond in the event of a catastrophic disaster. The example of PLN underscores the need to build flexibility and resilience into contractual obligations in the event of a demand shock. Additionally, a utility with high debt-to-revenue ratios is less able to sustain financial shocks and adapt to sudden market changes. Responsible corporate financial management is not only a matter for attracting external investment, but also a means of ensuring operational efficiency.

\subsection{Clean Energy and Power System Resilience}

Clean energy technologies - from renewable energy and energy efficiency to storage and smart grids - play an important role in the resilience of the power sector, bridging mitigation and adaptation to provide win-win scenarios for economic growth, resilience, and human health (Cox et al. 2017). These technologies are readily available today, are cost competitive, and can be deployed rapidly, often with shorter construction timelines than fossil alternatives.

- Diversification: Generation resources can be diversified in relation to geography, fuel type, and water use to support a more resilient power system. As part of a portfolio-diversification strategy, renewable energy and energy efficiency technologies provide a power source that is based on indigenous resources, independent of fuel imports or fuel price fluctuations. Wind and solar can harness the geographic diversity of wind and sun, smoothing out generation profiles to reduce variability, and their geographic diversity can also lessen impacts 
from disaster events. Multilateral cross-border power trading is another approach that could help SE Asian countries diversify and facilitate the integration of renewables by sharing resources in the region and mitigating imbalances (IEA 2019a).

- Distributed Generation: Distributed energy resources, which are connected at lower voltages and often close to load, can provide an important solution to scale up and deploy generation quickly to meet growing demand, especially as urbanization increases. Distributed generation, when coupled with storage, can support critical loads in the event of disasters, providing reliable microgrid solutions for facilities such as hospitals, water treatment, and emergency services.

- Energy Efficiency and Demand Side Management: Energy efficiency is an integral part of resilience of the power system. Efficiency reduces the long term need for increased supply, reducing the need to build more peaking capacity as demand continues to rise across Southeast Asia. Demand response and other demand side management measures can be tapped into in response to extreme events, reducing peak loads and the potential for system instability. Building energy codes along with improved appliance efficiency can reduce overall demand from a rapidly growing sector, reducing peak load needs and improving system reliability. 


\section{Path Forward}

COVID-19 has exacted a major toll on the populations and economies of SE Asia. The resulting pandemic response measures undertaken by governments of the region have had significant impacts on power sectors, which have in turn exposed and exacerbated existing vulnerabilities. This experience has underscored the need for power sector entities, their regulators, and policymakers in the SE Asia region to build resilience into their planning and operational protocols. A resilient power sector is one that can anticipate, prepare for, and adapt to changing conditions and withstand, respond to, and recover rapidly from disruptions (Stout et al. 2019). Building long-term resilience requires holistic planning, robust policies, and the deployment of technical and institutional solutions.

Among the measures that reinforce resilience are diversifying the power sector beyond carbon-intensive central station generation and moving toward a diversified generation mix that includes renewables, energy efficiency, and distributed resources. These technologies allow for clean, modular, distributed, and resilient options for responding to and managing power sector disruptions. Moreover, diversifying with clean energy sources has a suite of co-benefits that include air quality improvements, energy independence, reduction of trade imbalances from fossil imports, and local economic development.

Setting sights on the deployment of clean energy provides a pathway for SE Asia toward a "green" economic recovery that creates jobs, improves human health, enhances resilience, and meets growing energy demands for economic expansion. In the short term, the COVID-19 pandemic allowed countries to realize some of these benefits, with significant improvements in air quality, emissions, and renewable energy dispatch. Combining ambitious clean energy deployment goals with economic stimulus plans can create local jobs, improve air quality, strengthen power sector resilience, and meet growing demand in a region that is undergoing economic expansion even in the face of a global lockdown. The pandemic affords SE Asian governments an opportunity to take stock of their countries' trajectories and pursue policy and regulatory measures that will link recovery with sustainable development objectives.

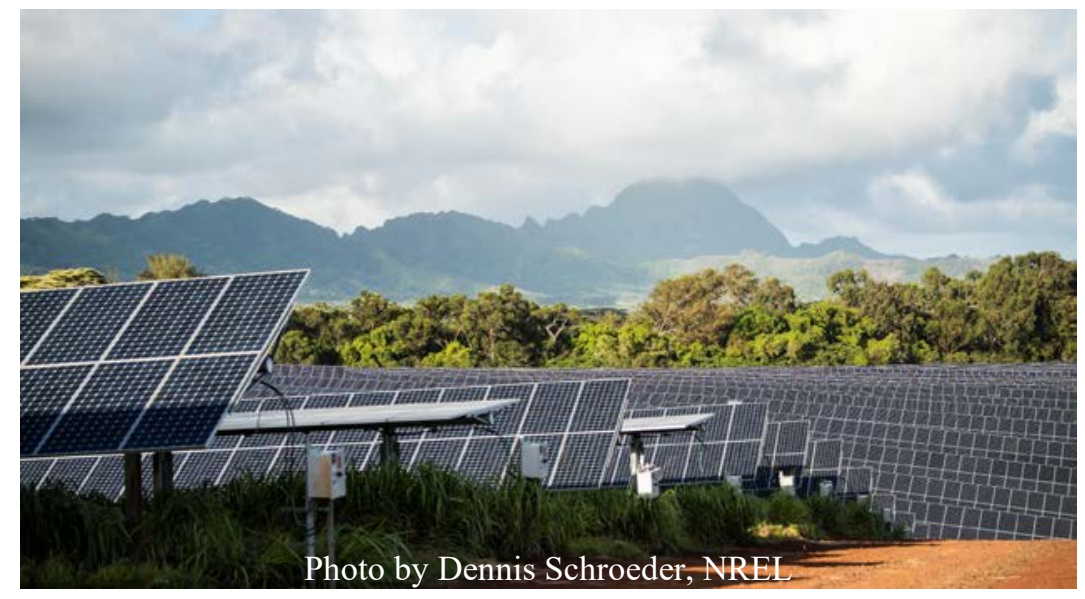




\section{References}

ACE, and IRENA. 2016. Renewable Energy Outlook for ASEAN. ASEAN Centre for Energy (ACE), Jakarta and International Renewable Energy Agency (IRENA), Abu Dhabi. https://www.irena.org/publications/2016/Oct/Re newable-Energy-Outlook-for-ASEAN.

ADB. 2019. "ADB-Supported Solar Project in Cambodia Achieves Lowest-Ever Tariff in ASEAN." Asian Development Bank (ADB. 2019. https://www.adb.org/news/adb-supportedsolar-project-cambodia-achieves-lowest-evertariff-asean.

AHA Centre. 2020. "Total Reported Natural Disaster in Southeast Asia." ASEAN Coordinating Centre for Humanitarian Assistance on Disaster Management (AHA Centre). The Column. 2020. https://thecolumn.ahacentre.org/posts/insightposts/vol-40-total-reported-natural-disaster-inshouteast-asia/.

Bangkok Post. 2020. "In the Time of Covid-19: Government Agencies Launch Plans to Relieve Utility Bill Pressures amid COVID-19." 2020. https://www.bangkokpost.com/life/social-andlifestyle/1906730/in-the-time-of-covid-19.

Brown, Matt, and Matthew Heling. 2020. "Renewable Energy in Southeast Asia: Unlocking Opportunities in a World on Lockdown." Presentation. Stockholm: AFRY. https://afry.com/en/newsroom/news/renewableenergy-in-southeast-asia-unlockingopportunities-in-world-lockdown.

Brown, Melissa. 2020. "PLN in Crisis - Time for Independent Power Producers to Share the Pain?" Cleveland, Ohio: Institute for Energy Economics and Financial Analysis (IEEFA). https://ieefa.org/wpcontent/uploads/2020/04/PLN_Time-for-IPPsto-Share-the-Pain April-2020.pdf.

Bruguera, Maya, Molly Hellmuth, and Derina Man. 2019. "Power Sector Resilience: Integrated Resource and Resilience Planning.” Resilient Energy Platform. New York: ICF. https://resilient-energy.org/training-andresources/quick-reads/19514 usaidnrel_irrp factsheet-v7-release.pdf/view.

CDC. 2020. "Coronavirus Disease 2019 (COVID-19)." Centers for Disease Control and Prevention (CDC). 2020. https://www.cdc.gov/coronavirus/2019ncov/faq.html.
Center for Strategic \& International Studies. 2020. "Southeast Asia Covid-19 Tracker | Center for Strategic and International Studies." Center for Strategic \& International Studies (CSIS). 2020. https://www.csis.org/programs/southeast-asiaprogram/southeast-asia-covid-19-tracker-0.

Chaturvedi, Apurva, and Vikas Gaba. 2020. "The Impact of COVID-19 on the Indian Power Sector." New Delhi: United States Agency for International Development (USAID). https://www.eqmagpro.com/wpcontent/uploads/2020/04/Covid19-Impact-onIndian-Power-Sector compressed-1.pdf.

CNA. 2020a. "Southeast Asia's Hydropower Boom Grinds to a Halt as COVID-19 Stalls Projects." Channel News Asia (CNA). 2020. https://www.channelnewsasia.com/news/asia/so utheast-asia-hydropower-boom-covid-19coronavirus-12652202.

_. 2020b. "Southeast Asia's Renewable Energy Transition Likely to Take Hit from COVID-19: Experts." Channel News Asia (CNA). 2020. https://www.channelnewsasia.com/news/asia/co vid19-southeast-asia-renewable-energy-nuclearasean-12617520.

Cox, Sadie, Eliza Hotchkiss, Dan Bilello, Andrea Watson, Alison Holm, and Jennifer Leisch. 2017. Bridging Climate Change Resilience and Mitigation in the Electricity Sector Through Renewable Energy and Energy Efficiency: Emerging Climate Change and Development Topics for Energy Sector Transformation. NREL/TP-6A20-67040. Golden, CO: National Renewable Energy Laboratory (NREL). https://www.nrel.gov/docs/fy18osti/67040.pdf.

Ernst \& Young Global. 2014. "EY - Indonesia's Plan to Increase Its Electricity Capacity - EY Indonesia.” Indonesia's Plan to Increase Its Electricity Capacity. 2014. https://www.fsinsights.ey.com/id/en/home/eyindonesias-plan-to-increase-its-electricitycapacity.

ESCC. 2020. Assessing and Mitigating the Novel Coronavirus (COVID-19): A Resource Guide. Washington, D.C.: Electricity Subsector Coordinating Council. https://www.electricitysubsector.org//media/Files/ESCC/Documents/ESCC COVID Resource Guide v203242020.ashx?1a=en\&hash $=$ D3732CBFB4682 7AA0331277E8D5CBE0CC4DFC3BF. 
Ibrahim, Azeem. 2020. “China's Coronavirus Debt Traps Are Coming." Foreign Policy. 2020. https://foreignpolicy.com/2020/03/23/chinacoronavirus-belt-and-road-bri-boost-debtdiplomacy/.

IEA. 2017. World Energy Outlook 2017 Special Report: Southeast Asia Energy Outlook. Paris: International Energy Agency (IEA). https://webstore.iea.org/weo-2017-specialreport-southeast-asia-energy-outlook. . 2018. "Air Conditioning Use Emerges as One of the Key Drivers of Global ElectricityDemand Growth.” International Energy Agency (IEA). 2018. https://www.iea.org/news/airconditioning-use-emerges-as-one-of-the-keydrivers-of-global-electricity-demand-growth. . 2019a. ASEAN Renewable Energy Integration Analysis. Paris: International Energy Agency (IEA). https://www.iea.org/reports/aseanrenewable-energy-integration-analysis. 2019b. Southeast Asia Energy Outlook 2019. Paris: International Energy Agency (IEA). https://webstore.iea.org/southeast-asia-energyoutlook-2019.

2019c. The Future of Cooling in Southeast Asia.

Paris: International Energy Agency (IEA). https://www.iea.org/reports/the-future-ofcooling-in-southeast-asia. 2020a. Global Energy Review 2020. Paris: International Energy Agency (IEA). https://www.iea.org/reports/global-energyreview-2020.

2020b. Renewable Energy Market Update. Paris: International Energy Agency (IEA). https://www.iea.org/reports/renewable-energymarket-update.

IMF. 2020. World Economic Outlook. Paris: International Monetary Fund (IMF). https://www.imf.org/en/Publications/WEO/Issue s/2020/04/14/weo-april-2020.

Insurance Information Institute, and Munich Re. 2020. "Facts + Statistics: Global Catastrophes | III." Insurance Information Institute (Iii). 2020. https://www.iii.org/fact-statistic/facts-statisticsglobal-catastrophes.

IRENA. 2020. Measuring the Socio-Economics of Transition: Focus on Jobs. Abu Dhabi: International Renewable Energy Agency (IRENA). https://www.irena.org/publications/2020/Feb/Me asuring-the-socioeconomics-of-transition-Focuson-jobs.
Kaushik, Tara S., Todd F. Kimbrough, and Dane McKaughan. 2020. "An Overview of Potential Solutions for Electric Utilities to Address COVID-19 Effects." Holland \& Knight. 2020. https://www.hklaw.com/en/insights/publications /2020/03/an-overview-of-potential-solutions-forelectric-utilities.

KPMG. 2020. "Government Response - Global Landscape - KPMG Global.” KPMG. 2020. https://home.kpmg/xx/en/home/insights/2020/04 government-response-global-landscape.html.

LBNL. 2020. "The Sendai Microgrid.” Lawrence Berkeley National Laboratory. 2020. https://building-microgrid.lbl.gov/sendaimicrogrid.

Lee, Nathan, Francisco Flores-Espino, Ricardo Oliveira, Billy Roberts, Thomas Bowen, and Jessica Katz. 2019. Exploring Renewable Energy Opportunities in Select Southeast Asian Countries: A Geospatial Analysis of the Levelized Cost of Energy of Utility-Scale Wind and Solar Photovoltaics. Technical Report. Golden, CO: National Renewable Energy Laboratory (NREL). https://www.nrel.gov/docs/fy19osti/71814.pdf.

Lee, Nathan, and Sherry Stout. 2019. "Planning a Resilient Power Sector: Ensuring Reliable, Secure, Safe, and Affordable Electricity." Golden, CO: National Renewable Energy Laboratory (NREL). https://www.nrel.gov/docs/fy19osti/73618.pdf.

Littell, David, Camille Kadoch, Ranjit Bharvirkar, Max Dupuy, Brenda Hausauer, Carl Linvill, Janine Migden-Ostrander, et al. 2018. "NextGeneration Performance-Based Regulation: Volume 1 (Introduction-Global Lessons for Success)." Regulatory Assistance Project. 2018. https://www.raponline.org/knowledgecenter/next-generation-performance-basedregulation-volume-1-introduction-globallessons-for-success/.

Lowder, Travis, Jeffrey Logan, and Emily Chen. 2019. Innovative Utility Offerings at the Distribution Edge: Case Studies from Around the Globe. NREL/TP-7A40-73800. Golden, CO: National Renewable Energy Laboratory (NREL). https://www.nrel.gov/docs/fy19osti/73800.pdf.

MERALCO. 2020a. "Understanding Your May Bill." Meralco. 2020. https://company.meralco.com.ph/news-andadvisories/understanding-your-may-bill. 
—. 2020b. "Universal Charge Increases Rates." MERALCO. 2020.

https://company.meralco.com.ph/videos/advisor $\mathrm{y} /$ meralco-advisory-april-2020.

Nery, Maria Cristina D. 2018. "One Third of Global Air Pollution Deaths in Asia Pacific." World Heath Organization (WHO). 2018.

https://www.who.int/westernpacific/news/detail/ 02-05-2018-one-third-of-global-air-pollutiondeaths-in-asia-pacific.

PFAN. 2020. "PFAN'S Covid-19 Response." Private Financing Advisory Network (PFAN). 2020. https://pfan.net/covid-19-response/.

Philippines DOE. 2018. “Adoption of Energy Resiliency in the Planning and Programming of the Energy Sector to Mitigate Potential Impacts of Disasters.” Department Circular DC2018-010001. Manila, Philippines: Philippines

Department of Energy (DOE). https://www.doe.gov.ph/sites/default/files/pdf/is suances/dc2018-01-0001.pdf.

Rios, Lara M. 2020. “COVID-19: Energy Project Financing Considerations." Holland \& Knight. 2020. https://www.hklaw.com/en/insights/publications /2020/03/covid-19-energy-project-financingconsiderations.

Rivera, Danessa. 2020. "Power Consumption Drops 30\% amid Luzon-Wide Quarantine." Philstar. 2020.

https://www.philstar.com/business/2020/03/22/2 002565/power-consumption-drops-30-amidluzon-wide-quarantine.

Scheller, Maria, and Ananth Chikkatur. 2014.

"Integrated Resource Planning Models Need Stronger Resiliency Analysis." Fairfax, VA: ICF International.

https://www.ourenergypolicy.org/wpcontent/uploads/2014/10/Integrated Resource P lanning Models Need Stronger_Resiliency An alysis.pdf.

Searight, Amy. 2020. "Commentary: The Economic Toll of Covid-19 on Southeast Asia: Recession Looms as Growth Prospects Dim." Center for Strategic \& International Studies (CSIS). 2020. https://www.csis.org/analysis/economic-tollcovid-19-southeast-asia-recession-loomsgrowth-prospects-dim.

Sheiner, Louise, and Kadija Yilla. 2020. "The ABCs of the Post-COVID Economic Recovery." Brookings. 2020. https://www.brookings.edu/blog/upfront $/ 2020 / 05 / 04 /$ the-abcs-of-the-post-covideconomic-recovery/.
Singapore Energy Market Authority. 2020. "Publications and Statistics: Half-Hourly System Demand Data." Singapore Energy Market Authority. 2020.

https://www.ema.gov.sg/statistic.aspx?sta_sid=2 0140826Y84sgBebjwKV.

Singapore Ministry of Health. 2020. "Circuit Breaker to Minimise Further Spread of COVID-19."

Singapore Ministry of Health (MOH). 2020. https://www.moh.gov.sg/newshighlights/details/circuit-breaker-to-minimisefurther-spread-of-covid-19.

Sommer, Lauren. 2020. "Why China's Air Has Been Cleaner During The Coronavirus Outbreak." National Public Radio (NPR). 2020. https://www.npr.org/sections/goatsandsoda/2020 /03/04/811019032/why-chinas-air-has-beencleaner-during-the-coronavirus-outbreak.

S\&P Global Platts. 2020. "Asian Buyers Face Potential Crude Allocation Cuts as Middle East Suppliers Aim to Balance Market | S\&P Global Platts." S\&P Global Platts. 2020. https://www.spglobal.com/platts/en/marketinsights/videos/market-movers-asia/051820crude-supply-coronavirus-recovery.

Stebbing, Holly, Chris Down, and Kathryn Emmet. 2020. "The impact of COVID-19 on the power and renewables industry." Norton Rose Fulbright. 2020. https://www.nortonrosefulbright.com/dede/wissen/publications/be467bc7/the-impact-ofcovid-19-on-the-power-and-renewablesindustry.

Stout, Sherry, Nathan Lee, Sadie Cox, James Elsworth, and Jennifer Leisch. 2019. Power Sector Resilience Planning Guidebook: A Self-Guided Reference for Practitioners. Technical Report NREL/TP-7A40-73489. Golden, CO: National Renewable Energy Laboratory (NREL). https://www.nrel.gov/docs/fy19osti/73489.pdf.

Stout, Sherry, Nathan Lee, Jason Vogel, Lorine Giangola, and Jennifer Leisch. 2020. "Lao Power Sector Vulnerability Assessment and Resilience Action Plan.” Technical Report. Golden, CO: National Renewable Energy Laboratory (NREL). https://www.nrel.gov/docs/fy20osti/73069.pdf.

Suarez, Isabella, and Lauri Myllyvirta. 2020. "COVID19 Lockdowns across Southeast Asia Improve Air Quality - but Not Everywhere." Centre for Research on Energy and Clean Air. 2020. https://energyandcleanair.org/covid19lockdowns-across-southeast-asia/. 
Sulaiman, Stefanno Reinard. 2019. "Only 10 Percent of 35-GW Power Projects in Operation, PLN Data Show." The Jakarta Post. 2019.

https://www.thejakartapost.com/news/2019/07/0 2/only-10-percent-of-35-gw-power-projects-inoperation-pln-data-show.html.

Sutabutr, Twarath. 2020. "Re-Thinking Energy Policy in the Post-Covid19 Era." Presentation presented at the ASEAN Sustainable Energy Week 2020:

Webinar Series \#1, Bangkok. https://www.asewexpo.com/2020/download/webinar/re think.pdf.

U.S. Embassy in Cambodia. 2020. "COVID-19 Information.” U.S. Embassy in Cambodia. 2020. https://kh.usembassy.gov/covid-19-information/.

U.S. News \& World Report. 2020. "Mosques, Streets Quiet as Indonesia's Capital Tightens Rules." 2020.

https://www.usnews.com/news/world/articles/20 20-04-10/mosques-streets-quiet-as-indonesiascapital-tightens-rules.

USAID-NREL Partnership. 2020. "Planning for Power Sector Resilience." Resilient Energy Platform. 2020. https://resilient-energy.org/guidebook.

Walton, Robert. 2020. "Electric Grid Challenges Will Grow If COVID-19 Impacts Extend into Summer Demand Season: NERC." Utility Dive. 2020.

https://www.utilitydive.com/news/electric-gridchallenges-will-grow-if-covid-19-impactsextend-into-summer-d/576705/.

WHO. 2020a. "Air Pollution: Air Pollution in the SouthEast Asia Region.” World Health Organization (WHO). 2020.

https://www.who.int/southeastasia/healthtopics/air-pollution.

. 2020b. "Coronavirus Disease (COVID-19)

Pandemic." World Health Organization (WHO). 2020.

https://www.who.int/emergencies/diseases/novel -coronavirus-2019.
Wiazowski, Peter J., and Trevor Zeyl. 2020. "Legal Update: Contract Performance in a Coronavirus World: Force Majeure Clauses and the Doctrine of Frustration." Montreal: Norton Rose Fulbright. https://www.nortonrosefulbright.com//media/files/nrf/nrfweb/knowledgepdfs/contract-performance-in-a-coronavirusworld-force-majeure-clauses-and-the-doctrineof-frustration.pdf?la $=$ en\&revision $=\mathrm{dbce} 71 \mathrm{~d} 2$ 6784-460c-95a7-3e130c8065f4.

Wood Mackenzie. 2017. "Growth in Southeast Asian LNG and Power." Wood Mackenzie. 2017. https://www.woodmac.com/news/opinion/southe ast-asia-lng-power/.

.2020. "Coronavirus Impact Update." Wood Mackenzie. 2020.

https://www.woodmac.com/nslp/coronavirusresearch-hub/latest-views/.

World Bank. 2020a. "East Asia and the Pacific in the Time of COVID-19 - Regional Economic Update, April 2020." 2020. https://www.worldbank.org/en/region/eap/public ation/east-asia-pacific-economic-update. 2020b. "Most Commodity Prices to Drop in 2020 As Coronavirus Depresses Demand and Disrupts Supply.” 2020. https://www.worldbank.org/en/news/pressrelease/2020/04/23/most-commodity-prices-todrop-in-2020-as-coronavirus-depresses-demandand-disrupts-supply.

- 2020c. South Asia Economic Focus, Spring 2020: The Cursed Blessing of Public Banks. Washington D.C.: World Bank. https://openknowledge.worldbank.org/handle/10 986/33478.

Zhu, Yongjian, Jingui Xie, Fengming Huang, and Liqing Cao. 2020. "Association between Short-Term Exposure to Air Pollution and COVID-19 Infection: Evidence from China." Science of The Total Environment 727 (July): 138704. https://doi.org/10.1016/j.scitotenv.2020.138704. 


\section{Scott C. Bartos}

Regional Energy Advisor

USAID Regional Development Mission for Asia

U.S. Agency for International Development

Tel: +66-2-257-3000

Email: sbartos@usaid.gov

\section{Nathan Lee}

Technical Lead

Advanced Energy Partnership for Asia

National Renewable Energy Laboratory

Tel: +1 303-384-7241

Email: nathan.lee@nrel.gov
The USAID-NREL Advanced Energy Partnership for Asia helps partner countries address the technical challenges of transitioning to sustainable, secure, and market-driven energy sectors across Asia. More information can be found at: www.nrel.gov/usaid-partnership.
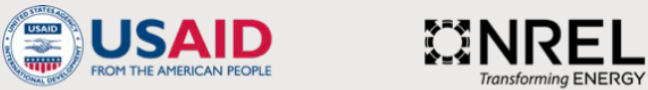

Advanced Energy Partnership for Asia operated by Alliance for Sustainable Energy, LLC, for the U.S. Department of Energy (DOE) under Contract No. DE-AC36-08GO28308. Funding provided by the United States Agency for International Development (USAID) under Contract No. IAG-19-2115. The views expressed in this report do not necessarily represent the views of the DOE or the U.S. Government, or any agency thereof, including USAID. 